Turkish Online Journal of Qualitative Inquiry (TOJQI)

Cilt 7, Say1 4, Ekim 2016: 331-363

DOI: $10.17569 /$ tojqi.79489

Araştırma Makalesi

\title{
Öğretim Elemanlarının Yaşamboyu Öğrenmeye Yönelik Görüşleri ${ }^{1}$
}

\author{
Halil İbrahim Haseski² ${ }^{2}$ Hatice Ferhan Odabaşı ${ }^{3}$
}

\section{$\ddot{O} \mathbf{z}$}

$\mathrm{Bu}$ çalışmanın amacı, öğretim elemanlarının yaşamboyu öğrenmeye yönelik düşüncelerini ve yaşamboyu öğrenme özelliklerini etkileyen faktörleri ortaya koymaktır. $\mathrm{Bu}$ amaç doğrultusunda söz konusu araştırma olgu bilim deseni ile desenlenmiştir. Araştırmanın örneklemi 2014-2015 eğitim-öğretim yılının güz döneminde Anadolu Üniversitesi’nin 17 fakültesinde faaliyet göstermekte olan profesör, doçent, yardımcı doçent ve araştırma görevlileri arasından seçilen 65 katılımcıdan oluşmaktadır. Söz konusu katılımcıların belirlenmesinde gönüllülük esası temelinde hareket edilmiş ve öğretim üyelerinin evren içindeki oransal dağılımına göre amaçlı örneklem alınmıştır. Araştırmanda ulaşılan veriler, araştırmacılar tarafından geliştirilen yarı yapılandırılmış görüşme formu ve yazılı görüşme formu kullanılarak elde edilmiş ve içerik analizi ile analiz edilmiştir. Araştırmanın sonucunda, öğretim elemanlarının yaşamboyu öğrenme kapsamında mesleki etkinliklere, sosyal etkinliklere ve kişisel gelişim etkinliklerine katıldıkları belirlenmiştir. Söz konusu sürece aktif katılımlarında akademisyenlerin kişisel, mesleki, kurumsal, toplumsal, akademik sistemin yapısı, teknoloji, bürokrasi ve yetersiz olanaklardan kaynaklı sorunlar yaşadıkları

\footnotetext{
${ }^{1} \mathrm{Bu}$ çalışma birinci yazarın doktora tezinden üretilmiştir.

${ }^{2}$ Yrd.Doç.Dr., Celal Bayar Üniversitesi, Eğitim Fakültesi, Bilgisayar ve Öğretim Teknolojileri Eğitimi Bölümü, Manisa/Türkiye, halil.haseski@cbu.edu.tr

${ }^{3}$ Prof.Dr., Anadolu Üniversitesi, Eğitim Fakültesi, Bilgisayar ve Öğretim Teknolojileri Eğitimi Bölümü, Eskişehir/Türkiye, fodabasi@anadolu.edu.tr

Geliş tarihi: 08.03.2016, Kabul tarihi: 29.10.2016
} 
belirlenmiştir. Öğretim elemanları, yaşamboyu öğrenmenin kişisel, mesleki ve sosyaltoplumsal açılardan, kendileri için önemli olduğunu ifade etmişlerdir. Bununla birlikte katılımcılar, yaşamboyu öğrenmeyi farklı boyutlarıyla tanımlamışlardır. Çalışmanın katılımcıları, öğretim elemanlarının yaşamboyu öğrenme özelliklerinin bireysel ve çevresel faktörlerden etkilendiğini belirtmişlerdir. Araştırmanın sonunda ulaşılan bulgular temelinde yüksek eğitim kurumları ve araştırmacılara yönelik çeşitli öneriler getirilmiştir.

Anahtar Sözcükler: Yaşamboyu öğrenme, ögretim elemanları, akademisyenler, yaşamboyu ögrenmede etkili faktörler 


\section{Giriş}

Günümüzde bilgi iletişim teknolojilerindeki hızlı gelişim, bilginin paylaşımını kolaylaştırmakta; hızla üretilen bilgi yine hızla tüketildiği için insanlarda öğrenme ihtiyacının artmasına yol açmaktadır. Bu süreç, öğrenme eyleminin okul sınırlarının ötesinde, yaşamboyu devam etmesi gerektiği zorunluluğunu ortaya çıkarmıştır (Knowles, 2009). Yaşamboyu öğrenme, her yaştan bireyin öğrenme sürecinin içinde yer almasını ve tüm bireylerin doğumlarından ölümlerine kadar ki süreçte, ihtiyaçlarına göre formal, informal ve non-formal öğrenme süreçlerine dâhil edilmesini ifade eden bir yaklaşımdır (UNESCO, 2013). Laal (2013a), yaşamboyu öğrenmeyi, bireylerin sosyal, kültürel ve ekonomik anlamda gelişiminin sağlanması amacıyla kişiselleştirilmiş ve esnek öğrenme fırsatlarının sunulması ile toplumsal bilincin ve demokratik anlayışın güçlenmesine olanak sunan bir süreç olarak ifade etmektedir. Biçerli (2012), yaşamboyu öğrenmeyi, yaş, sosyo-ekonomik statü ve eğitim seviyesi gibi sınırlar olmadan, okul ve okul dışı eğitimler kapsamında bilgi, beceri ve yeterliliklerinin geliştirilmesi amacıyla, bireylerin hayatları boyunca dâhil oldukları öğrenme faaliyetleri olarak tanımlamaktadır. Jarvis (2007), yaşamboyu öğrenmeyi, bireylerin yaşam süreci içerisinde var olduğu çevre ile etkileşim sonucunda edindiği deneyimler ile bedensel, zihinsel, duygusal alanların da dâhil olduğu, bütüncül anlamda bir gelişim gösterme ve kedini geliştirme süreci olarak ifade etmektedir. Yapılan tanımlarda yaşamboyu öğrenmenin, okulöncesi, okul ve okul sonrası dönemler dâhilinde, bireylerin tüm hayatını içine alan bir süreç olduğu; yaygın öğrenme, mesleki eğitim, teknik eğitim, hizmet içi ve hizmet dışı tüm eğitim ve öğretimler bağlamında bireylerin kişisel, sosyal ve mesleki anlamda gelişimlerini kapsadığ anlaşılmaktadır (Günüç, Odabaşı ve Kuzu, 2012).

Yaşamboyu öğrenme her yaştan birey için önem taşımasının yanında, günümüzde toplumların ilerlemesinde itici bir güç olan üniversitelerde faaliyet gösteren öğretim elemanlarının kendilerini geliştirmeleri için adeta bir zorunluluktur. Öğretim elemanları, yükseköğretim kurumlarında öğretim hizmeti veren ve/veya bilimsel araştırmalar gerçekleştiren kişilerdir. Üniversitelerin bünyesinde görev yapan öğretim yardımcıları olan çevirmenler, uzmanlar, öğretim planlamacıları, araştırma görevlileri, okutmanlar ve öğretim görevlileri ile öğretim üyeleri olan yardımcı doçentler, doçentler, profesörler ve ordinaryüs profesörler farklı derecelere sahip olan akademik personellerdir. Öğretim elemanları, bilimsel araştırma yapma, öğrenci yetiştirme, gerekli durumlarda toplumu bilim ışığında aydınlatma gibi çeşitli sorumluluklar taşıyan konu alanı uzmanlarıdır. Bu noktada öğretim elemanları hem 
öğreten hem de öğrenen bireyler olarak kendilerini çok boyutlu olarak geliştirmek durumundadirlar (Lunde ve Healy, 2002).

Alanyazında öğretim elemanlarının yaşamboyu öğrenme süreçlerini farklı açılardan konu alan araştırmalar bulunmaktadır. Bu kapsamda, öğretim elemanlarının mesleki açıdan gelişimlerinin sistematik olarak desteklenmesi gerektiğini ve bu süreçte teknolojinin etkili bir araç olarak kullanılabileceğini (Aggarwal, 2013; Kato, 2013; Latchem, Odabaşı ve Kabakçı, 2006) vurgulayan kuramsal çalışmalar, belli boyutlar kapsamında yaşamboyu öğrenme düzeyini belirlemeye yönelik ölçek geliştirme çalışmaları (Günüç, Odabaşı ve Kuzu, 2014; Kirby ve ark., 2010; Uzunboylu ve Hürsen, 2011), öğretim elemanlarına yönelik mesleki gelişim amacıyla düzenlenen programlarının etkililiğini inceleyen araştırmalar (Banks, 2002; Brown, 2001; Soran, Akkoyunlu ve Kavak, 2006) görülmektedir. Bunlar haricinde öğretim elemanlarının yaşamboyu öğrenmeye, yaşamboyu öğrenmenin önemine ve yaşamboyu öğrenme yeterliklerine yönelik görüşlerini belirlemeyi amaçlayan araştırmalar (Duta ve Rafaila, 2014;Köğce ve ark., 2014; Yavuz-Konokman ve Yanpar-Yelken, 2012) alanyazında yer almaktadır.

Konu ile ilgili gerçekleştirilen çalışmalar incelendiğinde, öğretim elemanlarının yaşamboyu öğrenme konusundaki mevcut durumlarını belirli boyutlar kapsamında tespit edilmesini amaçlayan araştırmaların ağırlık taşıdığı söylenebilir. Diğer yandan öğretim elemanlarının yaşamboyu öğrenme süreçlerinin daha kapsamlı olarak anlaşılması için konuyla ilgili görüşleri ile yaşamboyu öğrenme özelliklerini etkileyen faktörlerin detaylı olarak belirlenmesine yönelik araştırmalar yürütülmesi gereklidir. Bu araştırmanın amacı, öğretim elemanlarının yaşamboyu öğrenme hakkındaki düşüncelerini ve yaşamboyu öğrenme özelliklerini etkileyen faktörleri ortaya koymaktır. Böylelikle öğretim elemanlarının yaşamboyu öğrenme süreçlerine bütünsel bir bakış açısı sunulması hedeflenmektedir. Araştırmanın genel amacına yönelik olarak, aşağıdaki araştırma sorularına yanıt aranmaktadır:

1. Öğretim elemanlarının yaşamboyu öğrenme kapsamında katıldıkları etkinlikler, karşılaştıkları sorunlar, sorunlara yönelik çözüm önerileri nelerdir?

2. Öğretim elemanlarının yaşamboyu öğrenmenin önemine yönelik, tanımlanmasına yönelik düşünceleri nelerdir?

3. Öğretim elemanlarının yaşamboyu öğrenme özelliklerini etkileyen faktörler nelerdir? 


\section{Yöntem}

\section{Araştırmanın Deseni}

Bu çalışma, araştırma sorularına detaylı yanıtlar bulunmasını sağlayacağı için olgu bilim deseni ile desenlenmiştir. Olgu bilim deseni, bireylerin bilinen bir olguya ilişkin düşüncelerini kapsamlı olarak belirlemeye olanak veren bir araştırma yöntemidir (Yıldırım ve Şimşek, 2011).

\section{Araştırma Bağlamı ve Katılımcılar}

Araştırmanın evrenini, 2014-2015 eğitim-öğretim y1lı güz döneminde, Anadolu Üniversitesi'nin 17 fakültesinde faaliyet göstermekte olan, araştırma görevlisi, yardımcı doçent, doçent ve profesör unvanlarına sahip, toplam 1298 öğretim elemanı oluşturmaktadır. Araştırmada katılımcıların belirlenmesinde, gönüllülük esası temelinde hareket edilmiş ve öğretim üyelerinin evren içindeki oransal dağılımına göre amaçlı örneklem alınarak, 65 öğretim elemanı katılımcı olarak seçilmiştir. Böylelikle belirlenen evrenin \%5'ine ulaşılmıştır. Araştırmanın katılımcılarının cinsiyetlerine, akademik unvanlarına ve faaliyet gösterdikleri fakültelere göre dağılımları Tablo 1'de görülmektedir.

Tablo 1

Katılımcıların Cinsiyet, Akademik Unvan ve Fakültelere Göre Dağılımları

\begin{tabular}{|c|c|c|c|c|c|}
\hline Cinsiyet & $\mathrm{n}$ & $\%$ & Fakülteler & $\mathrm{n}$ & $\%$ \\
\hline Kadin & 32 & 49,2 & Fen Fakültesi & 3 & 4,6 \\
\hline Erkek & 33 & 50,8 & Güzel Sanatlar Fakültesi & 4 & 6,2 \\
\hline Toplam & 65 & 100 & Havacılık ve Uzay Bilimleri Fakültesi & 3 & 4,6 \\
\hline Akademik Unvan & & & Hukuk Fakültesi & 3 & 4,6 \\
\hline Profesör & 12 & 18,5 & İktisadi ve İdari Bilimler Fakültesi & 4 & 6,2 \\
\hline Doçent & 13 & 20 & İktisat Fakültesi & 3 & 4,6 \\
\hline Yardımcı Doçent & 20 & 30,8 & İletişim Bilimleri Fakültesi & 4 & 6,2 \\
\hline Araştırma Görevlisi & 20 & 30,8 & İşletme Fakültesi & 4 & 6,2 \\
\hline Toplam & 65 & 100 & Mimarlık ve Tasarım Fakültesi & 2 & 3,1 \\
\hline Fakülteler & & & Mühendislik Fakültesi & 2 & 3,1 \\
\hline Açıköğretim Fakültesi & 5 & 7,7 & Sağlık Bilimleri Fakültesi & 3 & 4,6 \\
\hline Eczacılık Fakültesi & 4 & 6,2 & Spor Bilimleri Fakültesi & 3 & 4,6 \\
\hline Edebiyat Fakültesi & 4 & 6,2 & Turizm Fakültesi & 3 & 4,6 \\
\hline Eğitim Fakültesi & 11 & 16,9 & Toplam & 65 & 100 \\
\hline
\end{tabular}


Bu araştırmanın Anadolu Üniversitesi’nde gerçekleştirilmesinin nedeni, söz konusu kurumun uzaktan eğitim ve yaşamboyu öğrenme alanında köklü bir geçmişe olması (Anadolu Üniversitesi, 2014; Kaya, 2014; Milli Eğitim Bakanlığı, 2012), kurum bünyesinde faaliyet gösteren öğretim elemanlarına bilimsel çalışmalar yürütmeleri konusunda önemli maddi destekler ve olanaklar sunmasından dolayıdır. Ayrıca söz konusu kurum, çalışmayı gerçekleştiren araştırmacıların faaliyet gösterdiği üniversite olmasından dolayı, veri toplama süreçlerinde kolaylık sağlanması açısından avantajlı bir konumdadır. Tüm bu nedenler göz önüne alındığında, araştırmanın amacına uygun niteliklere sahip bir yükseköğretim kurumu olmasından dolayı, çalışma ortamı olarak Anadolu Üniversitesi seçilmiştir.

\section{Veri Toplama Araçları}

Araştırmada elde edilen veriler, araştırmacılar tarafından geliştirilen yarı-yapılandırılmış görüşme formu ve yazılı görüşme formu kullanılarak toplanmıştır. Yarı-yapılandırılmış görüşme formu, öğretim elemanlarının yaşamboyu öğrenmeye yönelik düşünceleri ve yaşamboyu öğrenme özelliklerini etkileyen faktörlerin belirlenmesi amacıyla araştırmacılar tarafından hazırlanmıştır. Bu amaç doğrultusunda, yüz yüze görüşmeler aracılığıyla yanıt aranmak üzere açık uçlu sorular geliştirilerek, söz konusu veri toplama aracı oluşturulmuştur. Ayrıca, daha detaylı veri elde edilebilmesi için ek sorular da hazırlanmıştır. Yazılı görüşme formu, öğretim elemanlarının yaşamboyu öğrenmeye yönelik düşünceleri ve yaşamboyu öğrenme özelliklerini etkileyen faktörlerin belirlenmesi amacıyla araştırmacılar tarafından hazırlanmıştır. Bu amaç doğrultusunda, katılımcıların yazarak yanıtlamaları amacıyla açık uçlu sorular geliştirilerek, söz konusu veri toplama aracı oluşturulmuştur. Geliştirilen yazılı görüşme formunda, katılımcılara yönelik olarak açıklayıcı bilgiler de sunulmuştur. Araştırmada kullanılan veri toplama araçları, Bilgisayar ve Öğretim Teknolojileri Eğitimi alanında 7 konu alanı uzmanı, 3 ölçme uzmanı ve 1 dil uzmanının görüşüne sunulduktan sonra, örneklem ile benzer özellik taşıyan 3 öğretim elemanı ile pilot uygulama yapılarak, içerikteki soruların anlaşılırlığı test edilip, alınan dönütler doğrultusunda son haline getirilmiştir. Örneklem kapsamındaki katılımcılardan 26 kişi (evrenin \%2'si) ile yarı yapılandırılmış görüşme yapılarak, 39 kişiye de (evrenin \%3’ü) yazılı görüşme formu uygulanarak veri toplanmıştır. 


\section{Verilerin Toplanması ve Çözümlenmesi}

Araştırma kapsamında verilerin toplanmasından önce, Anadolu Üniversitesi Etik Kurulu'na başvuruda bulunulmuş ve çalışmanın etik açıdan gerçekleştirilebilirliğine ilişkin izin belgesi alınmıştır. Araştırmanın örneklemi dâhilindeki öğretim elemanlarıyla tek tek iletişime geçilip, randevu alınmış ve kendilerine en uygun olan yer ve zamanda, araştırmacı tarafindan bireysel olarak görüşülerek veri toplanmıştır. Çalışmanın inandırıcılığını sağlamak için farklı veri toplama teknikleri kullanılarak veri çeşitlemesine gidilmiştir. Ayrıca, veri kaynağı çeşitlemesini sağlamak için farklı özelliklerdeki katılımcılardan veri toplanmaya çalışılmıştır. Bununla birlikte, veri toplama sürecinde uzun süreli etkileşimi sağlama amacıyla katılımcı sayısı fazla tutulmuş ve 22 dakika ile 63 dakika arasında değişen sürelerde görüşmeler yürütülmüştür. Veri toplama araçlarının uygulanmasından önce katılımcılara, araştırmanın amacı, içeriği, toplanan verilerin nasıl kullanılacağı, katılımcıların hakları ve gizlilik ilkelerini içeren yazılı onay formu incelettirilmiş; bu bilgiler araştırmacı tarafından sözel olarak da açıklanmış ve tüm katılımcılardan araştırmaya gönüllü olarak katıldıklarına dair imza alınmıştır.

Yapılan görüşmelerdeki diyaloglar ses kayıt aleti ile kaydedilmiştir. Gerçekleştirilen görüşmeler esnasında katılımcılara, görüşmenin akışına göre sonda sorular yöneltilmiş ve daha detaylı veriler toplanmaya çalışılmıştır. Ayrıca, görüşme esnasında araştırmacı tarafından anlaşılamayan belirtimlerle ilgili olarak, katılımcılardan düşüncelerini daha detaylı olarak açıklamaları istenmiştir. Böylelikle, çalışmanın inandırıcılığının sağlanmasına yönelik veri toplama sürecinde derinlik odaklı bir yaklaşım izlenmiştir. Veri toplama sürecinde, görüşülen kişilerin belirttiği düşünceler, araştırmacı tarafından yönlendirici ya da yargılayıcı olmayan bir tutum ile dinlenmiş; olumlu bir iletişim ortamı oluşturularak, katılımcıların görüşlerini ve düşüncelerini özgürce ifade etmelerine firsat sunulmuştur. Gerçekleştirilen görüşmelerin bitiminde, araştırmacı tarafından toplanan verilere ilişsin katılımcılara bir özet yapılarak, verilerin doğruluğuna ilişkin onay alınmış ve araştırmanın inandırıcılığı sağlanmaya çalışılmıştır. Yapılan görüşmelerden sonra ses kayıtlarının yazıya dökülmesi işlemi gerçekleştirilmiştir. Yazıya dökülen görüşme kayıtlarında anlaşılamayan verilerin olması durumunda, ilgili katılımcı ile iletişime geçilip, görüşlerini açıklığa kavuşturması istenmiştir. Ayrıca araştırmanın örneklemi dâhilindeki katılımcılardan, yazılı görüşme formu aracılığı ile veri toplanmıştır. Söz konusu formlar, katılımcılara araştırmacı tarafından elden teslim edilmiş ve formlarda yer alan açık uçlu sorulara yazılı olarak yanıt vermeleri istenmiştir. Katılımcılar, 
söz konusu formları kendilerine en uygun zamanda yanıtlamışlar ve araştırmacıya elden teslim etmişlerdir.

Veri toplama süreci tamamlandıktan sonra, toplanan veriler içerik analizi yöntemi ile analiz edilmiştir. İçerik analizi, toplanan nitel verileri açıklayabilecek kavramlara ve ilişkilere ulaşmak amacıyla kullanılan bir yöntemdir (Yıldırım ve Şimşek, 2011). İçerik analizi süreci ile veriler, kategoriler ve temalar halinde kodlanmıştır. Böylece, öğretim elemanlarının yaşamboyu öğrenmeye yönelik düşüncelerine ve yaşamboyu öğrenme özelliklerini etkileyen faktörlere ulaşılmıştır. Söz konusu analiz süreci çalışmanın inandırıcılığını sağlamak amacıyla iki alan uzmanı tarafından gerçekleştirilmiş ve kodlamalarda tutarlılık sağlanmıştır. Yapılan nitel analiz sürecinde NVIVO 10 programından yararlanılmıştır. Analiz sonuçlarının raporlaştırılması sürecinde, araştırmanın aktarılabilirliğini sağlamak için katılımcıların ifadeleri doğrudan alıntılarla sunulmuştur.

\section{Bulgular ve Yorum}

\section{Öğretim Elemanlarının Yaşamboyu Öğrenme Kapsamında Katıldığı Etkinliklere İlişkin Bulgular}

Araştırmanın katılımcısı olan öğretim elemanları, çalışmanın birinci araştırma sorusu doğrultusunda, yaşamboyu öğrenme kapsamında hangi faaliyetlere katıldıklarına dair kendilerine yöneltilen soruya verdikleri yanıtlar içerik analizi ile analiz edilmiş ve Tablo 2'de yer alan temalar ve alt temalara ulaşılmıştır.

Tablo 2

Öğretim Elemanlarının Yaşamboyu Öğrenme Kapsamında Katıldı ̆̆g Etkinlikler

\begin{tabular}{|c|c|c|}
\hline Temalar ve Alt Temalar & $f$ & Katılımcıların İfadeleri \\
\hline \multicolumn{3}{|l|}{ Mesleki Etkinlikler } \\
\hline \multirow[t]{2}{*}{ Bilimsel } & 65 & “Sempozyumlar, kongreler ve panellere katılıyorum." [K3] \\
\hline & & “Kendi alanımla ilgili olan kitaplarl, makaleleri takip etmekteyim." [K54] \\
\hline \multirow[t]{2}{*}{ Eğitmenlik } & 17 & “Derse giriyorum. Ders öncesi bir hazırlık yapıp öğreniyorsunuz.” [K7] \\
\hline & & “Online ders verme süreçleri bana çok şey kattı.” [K29] \\
\hline İdari & 4 & "Dekan yardımcılı̆̆ı görevim idari yönden gelişimimi sağlıyor” [K13] \\
\hline
\end{tabular}




\begin{tabular}{|c|c|c|}
\hline Temalar ve Alt Temalar & $f$ & Katılımcıların İfadeleri \\
\hline \multicolumn{3}{|l|}{ Sosyal Etkinlikler } \\
\hline Kültürel & 28 & $\begin{array}{l}\text { “Tarih ögrenmek için müzeleri gezmeyi severim." [K32] } \\
\text { “Çeşitli konu ve alanlarda düzenlenen fuarlara katıllyorum." [K64] }\end{array}$ \\
\hline Sanatsal & 26 & $\begin{array}{l}\text { "Resim ile ilgiliyim. Bu konu ile ilgili ders de aldım." [K15] } \\
\text { "Dans etmeyi seviyorum. Modern danslarla ilgili ders allyorum." [K26] }\end{array}$ \\
\hline Spor & 12 & $\begin{array}{l}\text { "Futbol ile ilgileniyorum. Arkadaşlar ile maç yapıyoruz." [K2] } \\
\text { "Sağlıklı bir vücuda sahip olmak için vücut geliştirme yapıyorum." [K33] }\end{array}$ \\
\hline $\begin{array}{l}\text { Sivil Toplum } \\
\text { Çalışmaları }\end{array}$ & 10 & $\begin{array}{l}\text { “TEMA vakfi üyesiyim ve bu kurumda görevler üstleniyorum” [K15] } \\
\text { “Mesela UNICEF gönüllüsü olarak } 15 \text { yıl çalıştım.” [K26] }\end{array}$ \\
\hline \multicolumn{3}{|c|}{ Kişisel Gelişim Etkinlikleri } \\
\hline $\begin{array}{l}\text { İhtiyaçlara } \\
\text { Yönelik }\end{array}$ & 16 & $\begin{array}{l}\text { “Kendi oğlum için çocuk gelişimi üzerine kurs alıyorum.” [K19] } \\
\text { "Yemek yapma konusunda kendimi geliştirmeye çalışıyorum." [K23] }\end{array}$ \\
\hline BİT'e Yönelik & 15 & $\begin{array}{l}\text { “Güncel teknolojileri takip ederek kendimi geliştiriyorum.” [K39] } \\
\text { “Güncel olayları sosyal paylaşım ağlarından takip ediyorum.” [K55] }\end{array}$ \\
\hline Medya Takibi & 14 & $\begin{array}{l}\text { "Güncel olayları takip etmek için gazete okuyorum.” [K21] } \\
\text { "Televizyonda haberleri izliyorum.”[K31] }\end{array}$ \\
\hline
\end{tabular}

Tablo 2'de yer alan temaların frekansları incelendiğinde, katılımcıların yaşamboyu öğrenme kapsamında öncelikle bilimsel etkinliklere, sonrasında sırasıyla sosyal ve kişisel gelişim etkinliklerine katıldıkları söylenebilir.

\section{Öğretim Elemanlarının Yaşamboyu Öğrenme Sürecinde Karşılaştığı Sorunlara İlişkin Bulgular}

Araştırmanın katılımcısı olan öğretim elemanları, çalışmanın birinci araştırma sorusu doğrultusunda, yaşamboyu öğrenme kapsamında karşılaştıkları sorunlara yönelik olarak kendilerine yöneltilen soruya verdikleri yanıtlar, içerik analizi ile analiz edilmiş ve Tablo 3 'te yer alan temalar ve alt temalara ulaşılmıştır.

Tablo 3

Öğretim Elemanlarının Yaşamboyu Öğrenme Sürecinde Karşılaştı̆̆ Sorunlar

\begin{tabular}{|c|c|c|}
\hline Temalar ve Alt Temalar & $f$ & Katılımcıların İfadeleri \\
\hline \multicolumn{3}{|l|}{ Kişisel Sorunlar } \\
\hline Zaman Yönetimi & 25 & $\begin{array}{l}\text { "Zaman yönetiminde hata yapıp, farklı etkinliklere katılamıyorum." } \\
\text { [K62] }\end{array}$ \\
\hline Bireysel & 16 & "Bazı akademisyenler bir unvandan sonra rehavete kapıllyorlar" [K9] \\
\hline Farklılıklar & & “Bazı akademisyenler bilgiyi paylaşmak istemiyorlar” [K64] \\
\hline Evli Olma & 10 & $\begin{array}{l}\text { "Çocuğum nedeniyle uzak yerlerdeki kongrelere katılmıyorum” [K51] } \\
\text { "Bilimsel etkinlikler için şehir dışında ya da ülke dışında olmanız } \\
\text { gerekebiliyor. Bu konuda eşimle sıkıntılar yaşadığım oldu." [K65] }\end{array}$ \\
\hline
\end{tabular}




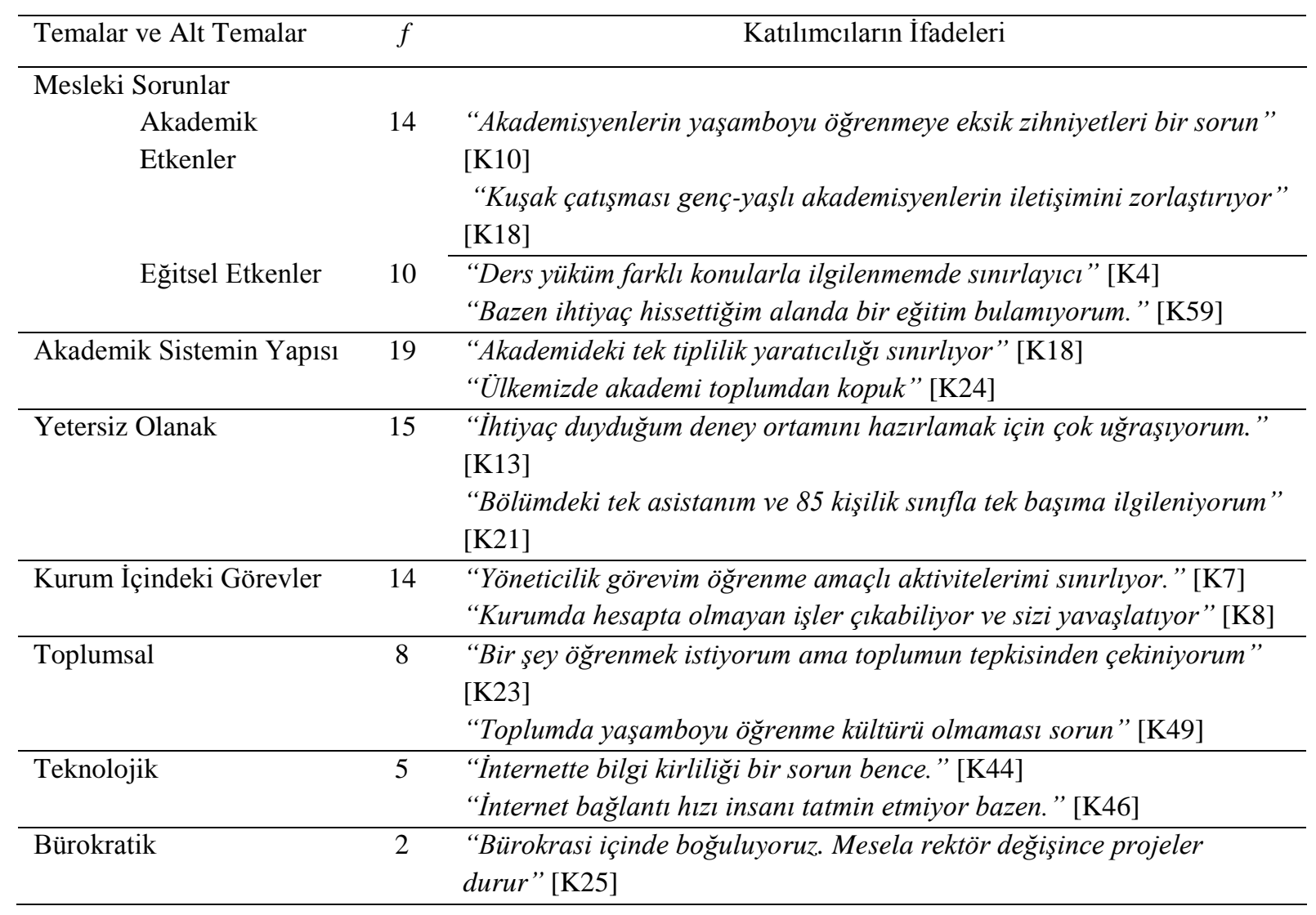

Tablo 3'te yer alan temaların frekansları incelendiğinde, katılımcıların yaşamboyu öğrenme sürecinde çoğunlukla kişisel sorunlar yaşadıkları anlaşılmaktadır. Buna ilaveten, söz konusu kişisel sorunları sırasıyla mesleki, akademik sistemin yapısı, olanak yetersizliği, kurum içindeki görevler, toplum, teknoloji ve bürokrasi bağlamında yaşanan sıkıntıların takip ettiği görülmektedir.

\section{Öğretim Elemanlarının Yaşamboyu Öğrenmede Karşılaştığı Sorunların Çözümüne İlişkin Bulgular}

Araştırmanın katılımcısı olan öğretim elemanları, çalışmanın birinci araştırma sorusu doğrultusunda, yaşamboyu öğrenme kapsamında karşılaştıkları sorunların çözümüne yönelik olarak, kendilerine yöneltilen soruya verdikleri yanıtlar içerik analizi ile analiz edilmiş ve Tablo 4'te yer alan temalara ulaşılmıştır. 
Tablo 4

Öğretim Elemanlarının Yaşamboyu Öğrenmede Karşılaştı̆̆ Sorunlara Yönelik Çözüm Önerileri

\begin{tabular}{|c|c|c|}
\hline Temalar & $f$ & Katılımcıların İfadeleri \\
\hline \multirow[t]{3}{*}{ Kişisel } & 13 & "Yașamboyu ö̆renme konusunda önceliklere göre çalıșllmalı." [K8] \\
\hline & & “Akademisyenlerin bu konuda birbirlerini olumlu anlamda etkilemeli." [K12] \\
\hline & & "Akademisyenlerin, zaman yönetimi becerilerini geliştirmeleri gerekli." [K17] \\
\hline Akademik & 6 & "Araştırma ve eğitim yapmak isteyen akademisyenlerin ayrıldığı bir sistem olmalı" \\
\hline Sistemin & & [K13] \\
\hline Yapis1 & & "Akademisyenlerin özlük hakları güçlendirilmeli." [K18] \\
\hline \multirow[t]{2}{*}{ Eğitsel } & 5 & "Lisansüstü derslerde bildiri ya da makale gibi bir ürün çıkartmak iyi olur." [K10] \\
\hline & & “Reklamlar yoluyla yaşamboyu öğrenme konusunda bilinç arttırılabilir” [K42] \\
\hline \multirow[t]{2}{*}{ Teknolojik } & 4 & "İnternet daha düzenli ve kolay ulaşllabilir bir kaynak olsaydv iyi olurdu" [K3] \\
\hline & & "İnternet konusunda altyapının iyileştirilmesi gerekli" [K46] \\
\hline \multirow[t]{2}{*}{ Kurumsal } & 4 & $\begin{array}{l}\text { "Uzmanlık alanımız dışındaki alanlarda geliş̧imimiz için üniversite bizi } \\
\text { desteklemeli" [K1] }\end{array}$ \\
\hline & & "İş-yaşam dengesini kurma konusunda kurumsal destek sağlanmast iyi olur" [K19] \\
\hline
\end{tabular}

Tablo 4'te yer alan temaların frekansları incelendiğinde, katılımcıların yaşamboyu öğrenme sürecinde karşılaştıkları sorunlara yönelik çoğunlukla kişisel çözüm önerileri getirdikleri anlaşılmaktadır.

\section{Öğretim Elemanları Açısından Yaşamboyu Öğrenmenin Önemine İlişkin Bulgular}

Araştırmanın katılımcısı olan öğretim elemanları, çalışmanın ikinci araştırma sorusu doğrultusunda, yaşamboyu öğrenmenin önemine ilişkin olarak kendilerine yöneltilen soruya verdikleri yanıtlar, içerik analizi ile analiz edilmiş ve Tablo 5 'te yer alan temalar ve alt temalara ulaşılmıştır.

Tablo 5

Öğretim Elemanlarına Göre Yaşamboyu Öğrenmenin Önemi

\begin{tabular}{|c|c|c|}
\hline Temalar & $f$ & Katılımcıların İfadeleri \\
\hline \multicolumn{3}{|l|}{ Mesleki } \\
\hline \multirow[t]{2}{*}{ Eğitsel Önem } & \multirow[t]{2}{*}{30} & “Öğrencilere örnek olmak için yaşamboyu öğrenme önemli” [K37] \\
\hline & & “Akademisyenlerin rol model olması açısından önemlidir.” [K45] \\
\hline \multirow{2}{*}{$\begin{array}{l}\text { Akademik } \\
\text { Önem }\end{array}$} & \multirow[t]{2}{*}{28} & "Yaşamboyu ögrenme akademik açıdan eskimemek için önemli." [K13] \\
\hline & & “Yaşamboyu öğrenme, bilimsel özgüveni devam ettirmek için önemli” [K62] \\
\hline \multirow[t]{2}{*}{ Kişisel } & \multirow[t]{2}{*}{25} & “Bizim için yaşamboyu ögrenme bir yaşam tarzı bence.” [K11] \\
\hline & & "Eleştirel değerlendirme ve eleştirel bakış açısı geliştirme için önemli”'[K32] \\
\hline \multirow[t]{2}{*}{ Sosyal-Toplumsal } & \multirow[t]{2}{*}{13} & $\begin{array}{l}\text { "Akademisyenlerin toplumu, toplumun da bizi daha iyi anlaması için önemli" } \\
\text { [K17] }\end{array}$ \\
\hline & & $\begin{array}{l}\text { "Toplumu bilinçlendirme sorumluluğumuzu yerine getirmemiz için önemli" } \\
\text { [K39] }\end{array}$ \\
\hline
\end{tabular}


Tablo 5'de yer alan temaların frekansları incelendiğinde, katılımcıların yaşamboyu öğrenmenin önemini ağırlıklı olarak mesleki, sonrasında sırasıyla kişisel ve sosyal-toplumsal açıdan dile getirdikleri anlaşılmaktadır.

\section{Öğretim Elemanları Açısından Yaşamboyu Öğrenmenin Tanımlamasına İlişkin Bulgular}

Araştırmanın katılımcısı olan öğretim elemanları, çalışmanın ikinci araştırma sorusu doğrultusunda, yaşamboyu öğrenmenin kendileri için nasıl tanımlandığına ilişkin yöneltilen soruya verdikleri yanıtlar, içerik analizi ile analiz edilmiş ve Tablo 6'da yer alan kodlara ulaşılmıştır.

Tablo 6

Öğretim Elemanlarına Göre Yaşamboyu Öğrenmenin Tanımı

\begin{tabular}{|c|c|c|}
\hline Kodlar & $f$ & Katılımcıların İfadeleri \\
\hline $\begin{array}{l}\text { Hayat Boyunca Sürekli } \\
\text { Öğrenmek }\end{array}$ & 47 & “Yaşamboyu öğrenme, beşikten mezara kadar ögrenmedir." [K17] \\
\hline $\begin{array}{l}\text { Formal, İnformal ve Non- } \\
\text { Formal Öğrenme } \\
\text { Süreçleri }\end{array}$ & 17 & $\begin{array}{l}\text { "Insanın her konuda formal ve informal ortamlarda öğrendiklerinin } \\
\text { tamamından oluşur ve bu bitmeyen bir süreçtir." [K15] }\end{array}$ \\
\hline Kişisel Gelişim & 10 & “Kişisel gelişim kapsamında yapılan öğrenme aktiviteleridir.” [K30] \\
\hline $\begin{array}{l}\text { Bilgi Edinmek Adına } \\
\text { Yapılan Her Şey }\end{array}$ & 9 & “Bilgi edinmek adına dair yaptığımız her şeydir.” [K20] \\
\hline Çağa Uyum Sağlamak & 8 & "Bireyin kendisini yenileyerek çağa uyum sağlaması" [K28] \\
\hline $\begin{array}{l}\text { İhtiyaçlar Doğrultusunda } \\
\text { Gelişmek }\end{array}$ & 5 & "Bireyin kendini ihtiyaç doğrultusunda geliştirebilmesidir.” [K13] \\
\hline $\begin{array}{l}\text { İlgiler Doğrultusunda } \\
\text { Öğrenmek }\end{array}$ & 4 & “Kişinin ilgileri kapsamında yapılan öğrenme aktiviteleridir.” [K30] \\
\hline Topluma Yararlı Olmak & 4 & $\begin{array}{l}\text { "Öğrenilen bilgileri toplumdaki bireylere aktarma ve onlara yararlı olma." } \\
\text { [K9] }\end{array}$ \\
\hline $\begin{array}{l}\text { Zamandan ve Mekândan } \\
\text { Bağımsız Öğrenmek }\end{array}$ & 3 & $\begin{array}{l}\text { "Bilgi, beceri ve yeterlilikleri zaman ve mekân sınırı olmadan geliş̧tirmek" } \\
\text { [K29] }\end{array}$ \\
\hline Mesleki Gelişim & 3 & "Bireyin kariyerinde ilerlemesi için kendini geliştirmesidir” [K1] \\
\hline Öğrenme Çabası & 3 & $\begin{array}{l}\text { "Yaşamboyu ögrenme, yeni bilgiler öğrenmek için çaba göstermektir.” } \\
\text { [K41] }\end{array}$ \\
\hline Hayat Tecrübesi & 3 & “Hayatımız boyunca edindiğimiz kümülatif tecrübe birikimi.” [K58] \\
\hline Farkındalık Sahibi Olmak & 3 & $\begin{array}{l}\text { "İnsanın yaşamı boyunca farkındalık sahibi olup kendisini geliştirmesi" } \\
\text { [K31] }\end{array}$ \\
\hline Sosyal Gelişim & 2 & "Bireyin sosyal olarak kendini geliştirmeye devam etmesi” [K54] \\
\hline Akademik Gelişim & 2 & $\begin{array}{l}\text { "Yaşamımız boyunca akademik anlamda kendimizi geliştirdiği bir süreç" } \\
\text { [K34] }\end{array}$ \\
\hline
\end{tabular}




\begin{tabular}{|c|c|c|}
\hline Kodlar & $f$ & Katılımcıların İfadeleri \\
\hline Öğrenme Merakı & 2 & “"̈̈̆renme merakına bağlı gerçekleşen bir gelişim süreci.” [K2] \\
\hline Bilgi İletişim & 2 & "Kişinin kendini başta bilgi iletişim teknolojilerini ve diğer kaynakları \\
\hline Teknolojilerini & & kullanarak yeni şeyler öğrenerek geliştirmesi.” [K36] \\
\hline Kullanmak & & \\
\hline Bir Kültür & 2 & “İkinci bir tanım yaparsak yaşamboyu ögrenme bir kültürdür” [K17] \\
\hline $\begin{array}{l}\text { Tüm İnsanları Kapsayan } \\
\text { Öğrenme Süreci }\end{array}$ & 1 & “Herkesi içeren, her an her dakika bilgi edinme sürecidir.” [K11] \\
\hline Çok Yönlü İletişim Süreci & 1 & "Bilginin paylaşılmasını sağlayan çok yönlü bir iletişim sürecidir.” [K58] \\
\hline $\begin{array}{l}\text { Kendini Geleceğe } \\
\text { Hazırlamak }\end{array}$ & 1 & “Bireyin kendini yetiştirerek geleceğe hazırlanmasıdır.” [K60] \\
\hline Kültürel Gelişim & 1 & "Bireylerin kendilerini geliştirerek, kültürel olarak ilerlemesi” [K33] \\
\hline Öğrenme Özgürlüğü & 1 & “Yaşamboyu öğrenme bana göre ögrrenme özgürlüğüdür. ” [K38] \\
\hline $\begin{array}{l}\text { İçsel Motivasyona Sahip } \\
\text { Olmak }\end{array}$ & 1 & $\begin{array}{l}\text { "İcsel motivasyona sahip olup yeni olanı ögrenme ve kendini yenileme” } \\
\text { [K16] }\end{array}$ \\
\hline Sorun Çözmek & 1 & $\begin{array}{l}\text { "Sorunlar karşısında çözüm ararken kendimizi geliştirip sorun çözmektir" } \\
\text { [K12] }\end{array}$ \\
\hline Sorgulamak & 1 & "Yaşarken sorgulayarak kendime bir şeyler kattığım durumlar" [K24] \\
\hline Bir Araştırma Süreci & 1 & “Yaşamboyu ögrenme bir araştırma ve öğrenme süreci.” [K65] \\
\hline $\begin{array}{l}\text { Bedenen ve Zihnen Canlı } \\
\text { Kalmak }\end{array}$ & 1 & $\begin{array}{l}\text { "Yaşamboyu öğrenmenin bir diğer ifadesi bence hem bedenen hem zihnen } \\
\text { canlı kalmak için bir öğrenme çabası demektir." [K65] }\end{array}$ \\
\hline Ruhun Doyurulması & 1 & “Kendimize yeni şeyler katarak ruhun doyurulmasıdır.” [K64] \\
\hline Para Kazanmak & 1 & "Para kazanabilmek için kendinizi sürekli geliştirme süreci” [K20] \\
\hline
\end{tabular}

Tablo 6 incelendiğinde katılımcıların yaşamboyu öğrenmeyi farklı açılardan tanımladıkları görülmektedir.

\section{Öğretim Elemanlarının Yaşamboyu Öğrenme Özelliklerini Etkileyen Bireysel ve Çevresel}

\section{Faktörlere İlişkin Bulgular}

Katılımcıların, çalışmanın üçüncü araştırma sorusu doğrultusunda, öğretim elemanlarının yaşamboyu öğrenme özelliklerini etkileyen faktörlerin neler olduğuna dair yöneltilen soruya verdikleri yanıtlar, içerik analizi ile analiz edilmiştir. Analiz sonucunda öğretim elemanlarının yaşamboyu öğrenme özelliklerinin hem çevresel hem de bireysel faktörlerden etkilendiğine yönelik temalar ve alt temalara ulaşılmıştır. Söz konusu bulgular sırasıyla Tablo 7 ve Tablo 8 de listelenmiştir. 
Tablo 7

Öğretim Elemanlarının Yaşamboyu Öğrenme Özelliklerini Etkileyen Çevresel Faktörler

\begin{tabular}{|c|c|c|}
\hline Çevresel Faktörler & $f$ & Katılımcıların İfadeleri \\
\hline \multicolumn{3}{|l|}{ Çalışılan Kurum } \\
\hline Kurumun Niteliği & 50 & $\begin{array}{l}\text { “Kurumun olanakları bireyleri kendilerini geliştirme konusunda önemli.” } \\
\text { [K2] }\end{array}$ \\
\hline & & “Kurumların yaşamboyu ögrenmeye verdikleri önemin etkili bence” [K8] \\
\hline Çalışma Ortamı & 24 & $\begin{array}{l}\text { “Akademisyenlerin rahatça çalışabilmesi için uygun çalışma ortamı } \\
\text { şart." [K4] }\end{array}$ \\
\hline Hocalar & 10 & $\begin{array}{l}\text { "Hocalarımın destekler yönde olması ve aktif çalışmaları bence etkili" } \\
\text { [K11] }\end{array}$ \\
\hline & & “Danışman hocanız bilgiye açıksa siz de öyle oluyorsunuz.” [K18] \\
\hline Kurum Yönetimi & 9 & “Üniversite yönetiminin bakış açısı bu konuda etkili bir faktördür” [K19] \\
\hline İş Arkadaşları & 8 & $\begin{array}{l}\text { "Çalışma ortamında meslektaşlarınızın yaptı̆̆ çalışmalar sizi de } \\
\text { etkiliyor” [K4] } \\
\text { "Farklı disiplinlerdeki iş arkadaşlarından yeni şeyler öğreniyoruz." } \\
\text { [K19] }\end{array}$ \\
\hline Öğrenciler & 6 & $\begin{array}{l}\text { “Öğrencilerle etkileşimlerimden çok şey öğreniyorum.” [K1] } \\
\text { “Öğrencilere uyum sağlamak için kendimizi geliştirmeye çalışıyoruz. , } \\
\text { [K14] }\end{array}$ \\
\hline Toplum & 25 & $\begin{array}{l}\text { “Toplumun kültürü yaşamboyu ögrrenmede önemli bence.” [K10] } \\
\text { “Toplumun bu konuda farkındalık sahibi olması etkili.” [K20] }\end{array}$ \\
\hline Bilgi İletişim Teknolojileri & 19 & $\begin{array}{l}\text { "Bilgi ve iletişim teknolojileri bilgiye ulaştırmayı kolaylaştırdığından ve } \\
\text { ilgi çekici kıldığından, yaşamboyu ögrenmeye aktif katılımı teşvik } \\
\text { etmektedir." [K56] }\end{array}$ \\
\hline Akademik Sistemin Yapısı & 19 & $\begin{array}{l}\text { “Akademisyenliğin gelişmeye zorlayıcı yapısı yaşamboyu ögrenmede } \\
\text { etkili”[K17] }\end{array}$ \\
\hline Çevre & 17 & $\begin{array}{l}\text { “Kendinizi geliştirme konusunda çevrenizdeki olanaklar sizi yönlendirir.” } \\
\text { [K26] } \\
\text { "Çevrenizdeki insanların okuyor olması sizi bu doğrultuda etkiler .” } \\
\text { [K60] }\end{array}$ \\
\hline Aile & 16 & $\begin{array}{l}\text { “Öğrenmeyi değer olarak gören bir ailede yetiştiyseniz bu olumlu } \\
\text { etkiler” [K10] } \\
\text { “Aile desteği yaşamboyu ögrenmede birey için etkili bence” [K11] }\end{array}$ \\
\hline Maddi Olanaklar & 10 & $\begin{array}{l}\text { “Dünyadaki ekonomik durum, bu konuda ayrllan kaynakları etkiler.” } \\
\text { [K25] } \\
\text { “Ülke ekonomisi yaşamboyu öğrenmeye ayırabildiği kaynakları etkiler” } \\
\text { [K56] }\end{array}$ \\
\hline Devlet Yönetimi & 10 & $\begin{array}{l}\text { "Yaşamboyu öğrenen bir toplum için bir kere politikalarını olacak ve bu } \\
\text { politikalarda süreklilik sağlanacak.” [K25] }\end{array}$ \\
\hline Medya & 7 & “Medya yaşamboyu öğrenmede etkili bir enstrüman” [K54] \\
\hline $\begin{array}{l}\text { Faaliyet Gösterilen Bilim } \\
\text { Dalı }\end{array}$ & 3 & $\begin{array}{l}\text { "Hukuk ve bu yaşayan bir alan. Alanımla ilgili yenilikleri öğrenmem } \\
\text { şart” [K7] } \\
\text { "Eczacılık dinamik bir alan. Alanım sürekli öğrenmemi zorunlu kllıyor." } \\
\text { [K13] }\end{array}$ \\
\hline
\end{tabular}


Tablo 7 incelendiğinde, çevresel faktörler kapsamında çalışılan kurumun, öğretim elemanlarının yaşamboyu öğrenme süreçlerinde önemli ölçüde gündeme geldiği belirtilebilir.

Tablo 8

Öğretim Elemanlarının Yaşamboyu Öğrenme Özelliklerini Etkileyen Bireysel Faktörler

\begin{tabular}{|c|c|c|}
\hline Bireysel Faktörler & $f$ & Katılımciların İfadeleri \\
\hline \multicolumn{3}{|l|}{ Kişisel Özellikler } \\
\hline Duyuşsal & 70 & “Bireyin yaşamboyu öğrenme sürecini nasıl algıladı̆̆ı önemli." [K1] \\
\hline & & $\begin{array}{l}\text { "Bence merak öğrenmeyi tetikleyen bir etken." [K7] } \\
\text { "Disinlinli olmantn öŏrenmeleri yönlendireceŏini düsünüyorum ,"[K11 }\end{array}$ \\
\hline Bilişsel Özellikler & 35 & $\begin{array}{l}\text { "Bence bireyin öğrenme öncelikleri yașamboyu öğrenmede etkili." [K10] } \\
\text { "Kendimizi geliştirebilmemiz için eleştirel düşünebilmek gerekiyor." [K14] }\end{array}$ \\
\hline Sosyal Özellikler & 8 & "Bireyin sosyal yeterlilikleri, diğer insanlardan ögrenmede önemli" [K12] \\
\hline $\begin{array}{l}\text { Psikolojik } \\
\text { Özellikler }\end{array}$ & 8 & $\begin{array}{l}\text { "Birey mutluysa, bu durum onun öğrenme motivasyonunu da olumlu } \\
\text { etkiler" [K5] "Yaşamboyu öğrenmede bireyin psikolojisinin sağllklı olması } \\
\text { önemli" [K41] }\end{array}$ \\
\hline Mesleki Özellikler & 28 & $\begin{array}{l}\text { "Akademik hayata bir memurluk olarak mı yoksa gelişsim süreci olarak mı } \\
\text { baktığınız yaşamboyu ögrenen olmada etkili." [K10] }\end{array}$ \\
\hline Külttürel Özellikler & 12 & $\begin{array}{l}\text { "Yaşamboyu öğrenmede geçmiş eğitim hayatımızın niteliği bence } \\
\text { etkili”[K23] } \\
\text { "Bireyin getirdiği külttürel alt yapı yaşamboyu öğrenmede etkili } \\
\text { diyebilirim." [K25] }\end{array}$ \\
\hline Ekonomik Özellikler & 6 & $\begin{array}{l}\text { "Ekonomik etkenler etkili. Bütçeniz kadar bir şeyler yapabiliyorsunuz" } \\
\text { [K23] }\end{array}$ \\
\hline
\end{tabular}

Tablo 8 incelendiğinde katılımcıların bireysel faktörler kapsamında kişisel özelliklere yönelik belirtimlerinin ön planda yer aldığı ifade edilebilir. Tablo 7 ve Tablo 8'de ulaşılan temaların frekansları göz önüne alındığında, ağırlıklı olarak çevresel faktörlerin ön plana çıktığı söylenebilir.

\section{Sonuç, Tartışma ve Öneriler}

\section{Öğretim Elemanlarının Yaşamboyu Öğrenme Kapsamında Katıldığı Etkinliklere İlişkin}

\section{Sonuçlar}

Araştırmada yer alan öğretim elemanlarının ağırlıklı olarak mesleki faaliyetlere, sonrasında sırasıyla sosyal ve kişisel gelişim etkinliklerine katıldıkları anlaşılmaktadır. $\mathrm{Bu}$ durumun nedeninin, mevcut akademik sistemde öğretim elemanlarına sunulan desteklerin bilimsel gelişim odaklı olması ve akademisyenleri bilimsel gelişime teşvik edip, diğer gelişim etkinliklerine katılımın ise öğretim elemanlarının kendi inisiyatiflerine ve çabalarına 
bırakılmasından kaynaklandığı söylenebilir. Buradan, mevcut akademik sistemin sunduğu olanakların ve sahip olduğu kriterlerin, öğretim elemanlarının bütünsel gelişimlerine destek sunma konusunda yetersiz kaldığ 1 ifade edilebilir.

\section{Öğretim Elemanlarının Yaşamboyu Öğrenme Sürecinde Karşılaştığı Sorunlar ve Çözüm Önerilerine İlişkin Sonuçlar}

Katılımcılar, yaşamboyu öğrenme sürecine etkin katılım konusunda sınırlayıcı ya da engel teşkil edici çeşitli sorunlarla karşılaştıklarını ifade etmişılerdir. Alanyazında katılımcıların da sorun yaşadıklarını ifade ettikleri bireysel faktörler olan planlı çalışmanın ve zamanı etkili yönetebilmenin öğrenmede önemli olduğu (Loyens, Magda ve Rikers, 2008) belirtilmektedir. Diğer yandan katılımcılar, bazı öğretim elemanlarının, kendilerini geliştirme sürecini ulaştıkları akademik unvanla sınırlayabildiklerini dile getirmişler ve mesleğe has bir sorununun gündeme gelmesini sağlamışlardır. Ayrıca katılımcılar, alanyazına paralel olarak sahip oldukları ailevi sorumluluklarının öğrenme süreçlerini engelleyebildiğine (Gouthro, 2005) ilişkin görüşler belirtmişlerdir. Buna ilaveten, bazı öğretim elemanlarının eşlerinin olumsuz tutumları sebebiyle bilimsel etkinliklere katılamadıkları konusundaki belirtimler, alanyazın açısından önem taşımaktadır. Söz konusu ailevi sorumlulukların bireyi sınırlamasının nedenlerinin, sahip olunan eksik zaman yönetimi becerileri, ailevi sorumlulukları etkili yönetememe ve bireylerin kültürel özellikleri gibi çeşitli faktörlerden kaynaklandığı düşünülmektedir.

Araştırmanın katılımcıları, akademik ve eğitsel anlamda sorunlarla karşılaştıklarını belirtmişlerdir. Bu doğrultuda katılımcılar, nitelikli eleman sayısının azlığından dolayı, kurum içinde yürütmek zorunda oldukları ders yüklerinin fazlalaştığını ifade etmişlerdir. Bu durum alanyazında kurumda üstlenilen görevlerin, yaşamboyu öğrenme sürecinde bireyleri sınırladığ1 (Clapper, 2010) görüşüyle paralellik taşımaktadır. Söz konusu sorunların çözümüne yönelik olarak bazı katılımcılar, öğretim elemanlarının araştırma yapan ve eğitim hizmeti sunan olmak üzere iki gruba ayrılması önerilerinde bulunmuşlardır.

Öğretim elemanları, alan yazındaki belirtimlere benzer olarak, faaliyet gösterdikleri kurumdaki diğer akademisyenlerin yaşamboyu öğrenmeye yönelik eksik zihniyetleri nedeniyle olumsuz örnek teşkil etmelerinin, kendilerini olumsuz olarak etkilediğini (Stewart, 2009) ifade etmişlerdir. Bunun haricinde katılımcılar, akademide öğretim elemanları arasında yaşanan kuşak çatışmasının iletişimde sorun yarattığını ve bu durumun yaşamboyu öğrenmede 
kendilerini sınırlayıcı olabildiğini ifade etmişlerdir. Söz konusu bulgunun, alanyazın açısından önemli olduğu düşünülmektedir.

Araştırmanın katılımcıları, alanyazında çevresel olanakların öğrenmede önemli olduğuna (Wolflin, 1999) yönelik belirtimlere benzer olarak, ihtiyaç duyulan eğitimleri bulamamalarının sınırlılık oluşturduğunu belirtmiştir. Diğer yandan çalışmanın katılımcıları, alanyazında toplumun yaşamboyu öğrenme anlayışının bireyi etkilediğine (Cedefop, 2003) yönelik belirtimlere paralel olarak, toplumun yaşamboyu öğrenme konusunda eksik bakış açısının ve kültürünün kendilerini sınırlayabildiğini ve yerine göre engelleyici nitelikte bir bask1 oluşturduğunu belirtmiştir.

Katılımcılar arasında bazı öğretim elemanları, akademik hayatta tek tiplilik yaşandığını ve akademide demokratik anlayış eksikliğinin bireylerin yaratıcılığını sınırlayabildiğini ifade etmişlerdir. Yaşamboyu öğrenme anlayışının bireysel farklılıklara saygı, demokrasi ve düşünce özgürlüğü temelinde şekillendiği (Martin, 2004) göz önüne alındığında, söz konusu durumun, yaşamboyu öğrenme düşüncesinin güçlendirilmesi önünde engel teşkil ettiği söylenebilir. Diğer yandan, araştırmaya katılan öğretim elemanları, mevcut akademik sistem içerisinde üniversitenin toplumdan kopuk olduğunu belirtmişlerdir. Yaşamboyu öğrenmenin yaşanılan toplumdan ve onun dinamiklerinden bağımsız olamayacağı düşünüldüğünde (Van Weert, 2005; Warren, 2004), mevcut akademik sistemin üniversite toplum etkileşimini destekleme ve güçlendirme konusunda yeterli olmamasının, yaşamboyu öğrenme anlayışının yaygınlaşmasını yavaşlattığı düşünülmektedir.

Araştırmanın katılımcıları, bilgi iletişim teknolojilerini kullanma konusunda ve internet üzerinden ihtiyaç duyulan doğru bilgiye ulaşma konusunda yaşadıkları sıkıntıların, kendilerini yaşamboyu öğrenme konusunda sınırladığını ifade etmişlerdir. Günümüzde teknoloji okuryazarlığg becerileri ve bilgi okuryazarlığg becerilerinin, yaşamboyu öğrenen olabilmek için her birey tarafından edinilmesi gereken beceriler olduğu (Diker-Coşkun, Kızılkaya Cumaoğlu ve Seçkin, 2013; Gürdal, 2000; Hammer, 2013; Laal, 2013a; Stasane, 2008) düşünüldüğünde, öğretim elemanlarının bu konuda desteklenmeleri gerektiği söylenebilir. Diğer yandan katılımcıların, ihtiyaç duydukları bilimsel kaynakların temin edilmesi konusunda bazen sıkıntılar yaşadıklarını, proje faaliyetleri yürütürken bürokratik engellerle karşılaştıklarını ifade etmeleri, konu ile ilgili bürokrasinin azaltılması için çalışmalar yapılması gerektiğini düşündürmektedir. 


\section{Öğretim Elemanları Açısından Yaşamboyu Öğrenmenin Önemine İlişkin Sonuçlar}

Araştırmanın katılımcıları, yaşamboyu öğrenmenin akademisyenler için önemli olduğuna inandıkları ve söz konusu önemi kişisel, mesleki ve sosyal-toplumsal açılardan dile getirdikleri söylenebilir. Bu kapsamda katılımcılar, alanyazındaki belirtimlere paralel olarak, yaşamboyu öğrenme sürecinin bireylerin kişisel gelişimlerinin sağlanması açısından önemli olduğunu (Kirby ve ark., 2010), eleştirel bakış açısıyla hareket edip (Scales, 2008), hayatın hızlı değişimine ayak uydurarak, her alanda görülen değişimi takip etmek ve kendilerini güncellemek için gerekli olduğunu (Güleç, Çelik ve Demirhan, 2012) ifade etmişlerdir.

Katılımcılar, yaşamboyu öğrenmenin mesleki açıdan önemini hem akademik hem de eğitsel anlamda dile getirmişlerdir. Buna göre öğretim elemanları, bilimle uğraştıkları için mesleğin doğası gereği yaşamboyu öğrenmenin önem taşıdığını düşünmektedir. Ayrıca konu alanlarındaki yeni gelişmeler karşısında sahip olunan akademik bilgileri yenileyip, mesleki öz güvenlerini devam ettirme; söz konusu öz güven doğrultusunda nitelikli yayınlar yaparak bilimde öncü olmak için yaşamboyu öğrenmenin önemli olduğunu ifade etmişlerdir. Diğer yandan öğretim elemanları, öğrenci yetiştirme görevi üstlendikleri için eğitmenlik görevini daha iyi bir şekilde yerine getirebilme ve öğrencilere örnek olabilme düşünceleriyle yaşamboyu öğrenmenin önemli olduğunu belirtmişlerdir.

Katılımcılar, yaşamboyu öğrenmenin kendileri için bir yaşam tarzı niteliği taşıdığını ifade ederek kişisel açıdan önemini dile getirmişlerdir. Bu belirtime paralel olarak Yavuz-Konokman ve Yanpar-Yelken (2014), öğretim elemanlarının sürekli öğrenme çabası içinde olduklarını ve yaşamboyu öğrenme yeterliliklerine sahip olmayı bir gereksinim olarak gördüklerini ifade etmiştir. Diğer yandan katılımcılar, üniversitelerin toplumsal sorumluluklara ve rollere sahip olduğu düşüncesi (Soran, Akkoyunlu ve Kavak, 2006) doğrultusunda, öğretim elemanlarının topluma ve sosyal çevrelerine karşı sorumluluk taşımalarından yola çıkarak, toplumu daha iyi anlayabilme ve toplum tarafından daha iyi anlaşılabilme amacıyla kendilerini sürekli geliştirmelerinin gerekli olduğunu ve bu nedenle yaşamboyu öğrenmenin akademisyenler için önem taşıdığını belirtmişlerdir.

Katılımcıların verdikleri yanıtların frekansları göz önüne alındığında, yaşamboyu öğrenmenin önemini ağırlıklı olarak mesleki gelişim temelinde ifade ettikleri, sonrasında ise sırayla kişisel ve sosyal-toplumsal açıdan yaşamboyu öğrenmeyi önemli gördükleri belirtilebilir. Bu durumun 
nedeninin, mevcut akademik sistemde mesleki gelişim odaklı teşvikler yapılmasının ve üniversite-toplum ilişkilerinin yeterince güçlendirilememiş olmasının, öğretim elemanlarının yaşamboyu öğrenmeye yönelik bakış açılarını etkilemesinden kaynaklı olduğu düşünülmektedir.

\section{Öğretim Elemanları Açısından Yaşamboyu Öğrenmenin Tanımlanmasına İlişkin Sonuçlar}

Araştırmanın katılımcısı olan öğretim elemanları, yaşamboyu öğrenmeyi farklı açılardan tanımlamışlardır. Söz konusu tanımlamalara bakıldığında, bireylerin hayatları boyunca sürekli öğrenmeleri düşüncesine ilişkin tanımların ön plana çıktı̆̆ı görülmektedir. Ayrıca katılımcılar, alanyazına paralel olarak, yaşamboyu öğrenmeyi öğrenme özgürlüğüne sahip olarak (Tuschling ve Engemann, 2006), zamandan ve mekândan bağımsız bir şekilde (Biesta, 2011), formal, informal ve non-formal öğrenme süreçleri kapsamında (Selvi, 2011), tüm insanların kendilerini geliştirmesi (AGE, 2014) çerçevesinde tanımlamalarda bulunmuşlardır. Bunlara ilaveten öğretim elemanları, yaşamboyu öğrenmeyi daha özele indirgeyerek, kişisel gelişim, mesleki gelişim, sosyal gelişim, kültürel gelişim ve akademik gelişimi sağlamaya yönelik öğrenme faaliyetleri bağlamında tanımlamalar yapmışlardır. Söz konusu ifadelerin, yaşamboyu öğrenmenin bireyin mesleki gelişimi de dâhil olmak üzere, kişisel, sosyal, kültürel ve bedensel açıdan kendini geliştirme süreci olduğu düşüncesiyle örtüştüğü ifade edilebilir (Jarvis, 2007; Laal, 2013b; Morgan-Klein ve Osborne, 2007; Preece, 2009). Diğer yandan bazı katılımc1lar, yaşamboyu öğrenmeyi topluma yararlı olmak ve toplumsal sistem içinde tutunmak amaciyla bireyin kendisini geliştirmesi kapsamında tanımlamışlardır.

Yapılan tanımların frekansları da göz önüne alındığında, öğretim elemanlarının yaşamboyu öğrenmeyi genel anlamda herkesi içine alan ve hayat boyu süren bir süreç olarak ifade ettikleri, özel de ise ağırlıklı olarak bireye dönük faydaları açısından tanımladıkları anlaşılmakta olup; sosyal ve toplumsal getirilere yönelik tanımlamaların nispeten daha az dile getirildiği belirtilebilir. Bu durumun nedenin, yaşamboyu öğrenme anlayışının ülkemizde bireyin mesleki gelişimi temelinde gerçekleşen bir gelişim süreci olarak algılanması ve söz konusu süreçte sosyal-toplumsal faydalara yönelik vurgunun geri planda kalmasından kaynaklı olduğu düşünülmektedir. 


\section{Öğretim Elemanlarının Yaşamboyu Öğrenme Özelliklerini Etkileyen Bireysel ve Çevresel Faktörlere İlişkin Sonuçlar}

Araştırmanın katılımcıları yaşamboyu öğrenme özelliklerinin bireysel ve çevresel faktörlerden etkilendiğini ifade etmişlerdir. $\mathrm{Bu}$ durum alanyazında yetişkin öğrenme süreçlerinin hem bireysel hem de çevresel faktörlerden etkilendiği (Jarvis, 2009) görüşüne benzerlik göstermektedir.

\section{Çevresel Faktörlere İlişkin Sonuçlar}

Çevresel faktörler bağlamında katılımcılar, akademisyenliğin gelişmeye zorlayıcı yapısının, öğretim elemanlarının kendilerini geliştirmeye sevk ettiğini ifade etmişlerdir. Ayrıca katılımcılar, faaliyet gösterdikleri kurumun sunduğu olanakların, maddi desteğin, kurumda oluşturulmuş olan çalışma kültürünün, kurumun yaşamboyu öğrenmeye verdiği önemin, kurum yönetiminin konuya ilişkin bilinç düzeyinin, bakış açısının ve desteğinin bu süreçte etkili olduğunu belirtmişlerdir. Bunun haricinde katılımcılar, çalışma ortamının yaşamboyu öğrenme kültürüne sahip olmasının, iş arkadaşlarının kendilerini geliştirme eğilimlerinin, öğretim elemanlarının yaşamboyu öğrenme sürecine katılımında etkili faktörler olduğunu dile getirmişlerdir. Diğer yandan katılımcılar, öğretim elemanlarının yeni nesil öğrencilere uyum sağlama girişimlerinin ve öğrencilerle etkileşimlerinin kendilerini geliştirme sürecinde etkili olduğunu belirtmişlerdir. Bunlara ilaveten öğretim elemanları, alanyazındaki belirtimlere benzer olarak, çalışılan bölümdeki hocaların niteliklerinin, destek ve teşviklerinin ve iyi model olmalarının öğretim elemanlarının yaşamboyu öğrenme sürecine etkin katılımını sağlayan faktörler olduğunu dile getirmişlerdir (Jarman, Mcaleese ve Mcconnell, 1997; Lunenberg, Korthagen ve Swennen, 2007; Steward, 2009).

Araştırmanın katılımcıları, alan yazında öğrenme anlayışı geliştirme konusunda ailenin niteliğinin önemli olduğuna (Bruce, 2011; Hendrick, 2015; Knoche, Cline ve Marvin, 2012) yönelik belirtimlere benzer olarak, bireylerin yetiştikleri aile ortamının ve yetişme şekillerinin, onları öğrenmeye daha açık kılabildiğini dile getirmiş, ayrıca ebeveyn desteğinin yaşamboyu öğrenme sürecinde etkili olduğunu ifade etmişlerdir. Bununla birlikte öğretim elemanları, seçilen eşin niteliğinin, bireyin yaşamboyu öğrenme sürecinde önemli ve etkili olduğunu vurgulamışlardır. Bunun haricinde katılımcılar, bireyin sosyal çevresinin yaşamboyu öğrenme konusunda bilinç düzeyinin ve çevrenin öğrenme konusunda sunduğu fırsatların niteliğinin, 
yaşamboyu öğrenme sürecinde kendilerini geliştirmeleri üzerinde etkili faktörlerden olduğunu belirtmişlerdir. Ayrıca katılımcılar, toplumun kültürel özelliklerinin, toplumun yaşamboyu öğrenme farkındalığının, toplumun yaşamboyu öğrenmeye yönelik algısının akademisyenlerin yaşamboyu öğrenme süreci üzerinde etkili olduğunu dile getirmişlerdir. Söz konusu belirtimlere benzer olarak, alanyazında bireylerin yaşadıkları çevre ve toplum içinde var oldukları ve bu faktörlerden etkilendikleri nitelendirilmektedir (Edwards, 1997; Jarvis, 2012; Medel-Añonuevo, Ohsako ve Mauch, 2001).

Katılımcılar, ekonomik etkenlerin yaşamboyu öğrenme anlayışının yaygınlaştırılmasında etkili olduğu (Falch ve Oosterbeek, 2011; Strain, 1998; Toprak ve Erdoğan, 2012) görüşüne benzer olarak, dünyanın ve ülkenin ekonomik şartları dâhilinde yaşamboyu öğrenme konusunda olanaklar sunulabildiğini, söz konusu şartların öğretim elemanlarının yaşamboyu öğrenen olmalarında etken oluşturduğunu ifade etmişlerdir. Buna ilaveten katılımcılar, yaşamboyu öğrenmeyi teşvik etme ve yaşamboyu öğrenme anlayışının toplumda yaygınlaştırma konusunda devlet yönetiminin alacağı kararların, toplumun gerçekleri, talepleri ve ihtiyaçları temelinde oluşturacağı stratejilerin ve politikaların önemli olduğunu ifade etmişlerdir. Söz konusu ifadeler, yaşamboyu öğrenme anlayışının yaygınlaşması amacıyla, devletlerin politikalar geliştirmesi (Gibb ve Walker, 2011; Lynch, 2008; Thompson, 2008) görüşüyle paralellik taşıdığı belirtilebilir.

Araştırmanın katılımcıları, alanyazındaki belirtimlere benzer olarak, bilgi iletişim teknolojilerinin istenilen bilgiye ulaşmayı, ulaşılan bilginin paylaşılmasını ve yayılmasını kolaylaştırdığını belirtip, söz konusu teknolojilerin kullanımının yaşamboyu öğrenmede etkili olduğunu ifade etmişlerdir (Dinevski ve Kokol, 2005; European Commission, 2007; Gorard, Selwyn ve Madden, 2003; Koper, 2004; Laal, 2013a). Buna ilaveten katılımcılar, alanyazına paralel olarak, medyanın toplum üzerinde kültürleyici etkisi olduğunu, söz konusu etkinin eğitsel amaçlarla kullanılarak, yaşamboyu öğrenme anlayışının ve bilincinin topluma benimsetilmesinin sağlanabileceği belirtmişlerdir (Falk ve Dierking, 2012; Flew, 2002; Hamilton, 2002; Kokhanova, 2012; Varavarn, 2010).

Araştırmanın katılımcıları arasından bazı öğretim elemanları, faaliyet gösterdikleri bilim alanlarına özgü değişim hızının yüksek olmasının, kendilerini mesleki anlamda gelişmeye ve sahip oldukları bilgileri daha hızlı olarak güncellemeye sevk ettiğini ifade etmişlerdir. Buradan, öğretim elemanlarının yaşamboyu öğrenme sürecine katılımlarında, faaliyet gösterdikleri bilim 
alanlarına has özelliklerin de etkili bir faktör olduğu söylenebilir. Söz konusu bulgunun alanyazın açısından önemli olduğu düşünülmektedir.

\section{Bireysel Faktörlere İlişkin Sonuçlar}

Katılımcılar, yaşamboyu öğrenmede bireysel faktörler kapsamında, alanyazındaki belirtimlere paralel olarak, bireyin kişisel, ekonomik, mesleki ve kültürel özelliklerinin etkili olduğunu ifade etmişlerdir (Çubukçu, 2011; Figel, 2007; Günüç, Odabaş1 ve Kuzu, 2012; Tan ve Morris, 2006; Walters ve Watters, 2001). Bu bağlamda öğretim elemanları, bireylerin sürekli öğrenme çabası göstermelerinin, bilgi okuryazarlığı becerilerinin, bilgi iletişim teknolojileri kullanma yeterliliklerinin, eleştirel bakış açılarının, zaman yönetimi becerilerinin, öz eleştiri ve öz değerlendirme gibi bilişsel yeterliklerinin yaşamboyu öğrenmede önemli olduğunu (Adams, 2007; Cornford, 2002; Crowther, 2004; Günüç, Odabaş1 ve Kuzu, 2012; Koç, 2007; Nyiri, 1997) dile getirmişlerdir.

Katılımcılar, duyuşsal özellikler bağlamında alanyazındaki belirtimlere paralel olarak bireyin öğrenme isteğinin ve güdüsünün, öğrenmeye yönelik motivasyonun, öğrenme konusunda öz güvenin, öğrenme merakının, öğrenmeye açık olmanın, öğrenme ihtiyacı hissetmenin, öğrenmede sebat göstermenin söz konusu süreçte etkili olduğunu (Bryce, 2006; European Commission, 2006a; Köymen, 2002; Nyiri, 1997; Schunk ve Pintrich, 2002; Slavin, 1994) ifade etmişlerdir. Bunların yanında katılımcılar, alanyazındaki belirtimlere benzer olarak, bireylerin hoşgörülü olmalarının, farklı fikirlere, eleştiriye ve işbirliğine açıklık düzeylerinin kendilerini geliştirme sürecinde önemli olduğunu belirtmişlerdir (Biesta, 2011; Çubukçu, 2011; Jarvis, 2008; Martin, 2004). Ayrıca öğretim elemanları, mesleki anlamda sorumluluk duygusuna sahip olmanın, mesleğini sevmenin ve bilim insanı olarak öz saygıya sahip olmanın bireyi öğrenmeye sevk eden etmenlerden olduğunu nitelendirmişlerdir. Bununla birlikte katılımcılar, öğrenme için diğer uğraşlarından fedakârlık etme isteğinin ve etik bilincine sahip olmanın (Figel, 2007; Köğce ve ark., 2014) önemli olduğuna dikkat çekip, alanyazında nispeten daha az dile getirilen düşünceleri vurgulamışlardır.

Araştırmanın katılımcıları, alanyazındaki belirtimlere paralel olarak, bireyin sosyal becerilerinin ve sahip olduğu maddi olanakların, yaşamboyu öğrenmede etkili olduğunu ifade etmişlerdir (Dong, 2004; Endrawes, 2010; European Commission, 2006b; Figel, 2007; Günüç, Odabaşı ve Kuzu, 2012; Yasukawa, 2009). Buna ilaveten katılımcılar, maddi getiri sağlayacak 
bilimsel çalışmalar yürütme isteğinin, öğrenme ve kendilerini geliştirme süreçlerini destekleyeceğini de dile getirmişlerdir. Diğer yandan katılımcılar, bireylerin mutlu ve geleceğe yönelik umutlu olmalarını sağlayacağı için olumlu ve sağlıklı psikolojik özelliklere sahip olmanın gerekli olduğuna dikkat çekmişler ve öğrenme süreçlerinin bireyin psikolojisinden etkilendiğini gündeme getirmişlerdir. Çalışma dâhilindeki akademisyenler, öğretim elemanlarının akademisyenlik mesleğine yönelik bakış açılarının önemli olduğunu, söz konusu mesleğin memurluk olarak ya da bir unvana erişmek için yapılan bir iş olarak görülmemesi gerektiğini belirtmişlerdir. Ayrıca katılımcılar, akademide yükselme isteklerinin, kendilerini geliştirmelerini destekleyici bir etken olabileceğini diğer yandan, esas amacın bir unvan elde etmek olması durumunda, hedeflerine ulaştıktan sonra kendilerini geliştirmekten vazgeçebileceğini ifade etmişlerdir. Söz konusu belirtimlerin, yaşamboyu öğrenme sürecinde öğretim elemanlarına özgü etkenleri nitelediği ve alanyazın açısından önem taşıdığı düşünülmektedir.

Çalışmanın katılımcısı olan öğretim elemanları, alanlarında yetkin olmanın, akademisyenlerin kendilerini geliştirmelerini teşvik edici bir faktör olduğunu ifade etmişlerdir. $\mathrm{Bu}$ ifadenin, alanyazında bireyin mesleğinde sahip olduğu deneyim ve yetkinlik durumunun, kendisini geliştirmeyi destekleyici bir etken olduğu (Knapper ve Cropley, 2000; Rotwell ve Kazanas, 1998) görüşüyle aynı doğrultuda olduğu söylenebilir. Diğer yandan çalışmanın katılımcıları, alanyazına paralel olarak, öğretim elemanlarının yabancı dil yeterlik düzeylerinin (Adams, 2007; Çubukçu, 2011; European Commission, 2002; Scales, 2008) ve derslerini güncelleme ihtiyaçlarının, kendilerini geliştirme sürecini desteklediğini ifade etmişlerdir. Ayrıca katılımcılar, öğretim elemanlarının yetiştiği kültürün ve geçmiş eğitim hayatının niteliğinin yaşamboyu öğrenmede aktif katılımcı olması konusunda etkili olduğunu vurgulamışlar (ELLI, 2010; European Commission, 2007; Holmes, 2002; Phoenix, 2002) ve alanyazın ile örtüşen görüşler dile getirmişlerdir.

Yaşamboyu öğrenmede etkili olan çevresel faktörlere yönelik belirtimlerin frekansları göz önünde bulundurulduğunda, katılımcıların ağırlıklı olarak çalışılan kurum bağlamında açıklamalar yaptığı söylenebilir. Bu durumun nedeninin, öğretim elemanlarının yaşamboyu öğrenmeye mesleki gelişim odaklı yaklaşmasından kaynaklı olduğu düşünülmektedir. Diğer yandan yaşamboyu öğrenmede etkili olan bireysel faktörlere yönelik belirtimlerin frekansları göz önünde bulundurulduğunda, katılımcıların ağırlıklı olarak kişisel özellikler bağlamında açıklamalar yaptığı söylenebilir. Bu kapsamda katılımcılar, sırayla bireylerin duyuşsal ve 
bilişsel özelliklerine yönelik faktörlerin etkili olduğunu ifade etmişlerdir. Diğer yandan öğretim elemanlarının, bireylerin sosyal ve psikolojik özelliklerine yönelik belirtimlerinin nispeten daha az olduğu anlaşılmaktadır. Kişisel özellikler haricinde öğretim elemanları, ağırlıklı olarak bireylerin mesleki özelliklerine yönelik faktörlerin etkili olduğunu dile getirdikleri görülmektedir. Buna karşın, kültürel ve ekonomik faktörlere yönelik görüşlerin frekansının düşük olduğu söylenebilir. Bu durumun nedenlerden birinin, yaşamboyu öğrenmede kişinin kendi öğrenme sorumluluğunu üstlenmesiyle birlikte, bilişsel ve duyuşsal özelliklerin önem kazanmasından kaynaklı olduğu ifade edilebilir. Ayrıca, söz konusu durumun diğer bir nedeninin ise ülkemizde yaşamboyu öğrenme anlayışının mesleki gelişim odaklı olması sonucu, sosyal, psikolojik ve kültürel etkenlerin nispeten geri planda değerlendirilmesinden kaynaklı olduğu söylenebilir.

Gerçekleştirilen araştırmanın sonuçları, Anadolu Üniversitesi bağlamı göz önüne alınarak değerlendirildiğinde, kurumun sunduğu geniş maddi olanakların, akademik gelişim kapsamında düzenlenen kurs ve seminerlerin, öğretim elemanlarının yaşamboyu öğrenme sürecini desteklemede önemli ve faydalı olduğu belirtilebilir. Diğer yandan, sunulan tüm olanaklara rağmen katılımcıların, yaşamboyu öğrenme konusunda sorunlar yaşadıkları belirlenmiştir. Söz konusu durumun nedeni olarak, yaşamboyu öğrenme süreci birçok faktörden etkilenen çok boyutlu bir yapı sergilemesine karşın, bu yapı tam olarak anlaşılmadığından konu ile ilgili kurum içinde yapılan faaliyetlerin eksik veya yetersiz kaldığı düşünülmektedir. Nitekim katılımcıların, yaşamboyu öğrenme kapsamında gerçekleştirdikleri etkinliklerin, yaşamboyu öğrenme kavramının önemine ve tanımlanmasına yönelik belirtimlerinin çoğunlukla mesleki gelişim temelinde şekillenmesinin söz konusu eksikliğe işaret ettiği söylenebilir. Buradan Anadolu Üniversitesi'nde mevcut yaşamboyu öğrenme anlayışının ağırlıklı olarak mesleki gelişim kapsamında olduğu ve öğretim elemanlarının konuyla ilgili mevcut bilinç düzeylerinin, bütünsel gelişimi sağlama doğrultusunda geliştirilmesi gerektiği ifade edilebilir.

Araştırmada ulaşılan sonuçlar doğrultusunda kurumlara, uygulamaya ve araştırmaya yönelik aşağıdaki öneriler getirilmiştir.

- Üniversitelerin toplumla daha güçlü bütünleşebilmelerini sağlamaya yönelik projeler geliştirilebilir. 
- Toplumda yaşamboyu öğrenme anlayışının yaygınlaştırılması konusunda, eğitim uzmanları, medya kurumları, sosyal toplum kuruluşları ve üniversiteler gibi konunun tüm paydaşlarının dâhil olduğu bir yapı içinde ülke çapında projeler geliştirilip, uygulanabilir.

- Yaşamboyu öğrenme konusunda iyi örnek olan ve alanlarında başarılar elde eden kişilerin, medya kurumları aracılığıyla gündeme getirilerek, tüm topluma olumlu rol model olmaları sağlanabilir.

- Devlet yönetimi, yaşamboyu öğrenme kapsamında hem toplum hem de akademisyenler için ulusal ve uluslararası ölçekte konu ile ilgili kurum ve kuruluşlarla ortaklıklar oluşturulmasını sağlayıp, yeni uygulamalara zemin hazırlanabilir.

- Devlet yönetimi, konunun uzmanları ve paydaşlarıyla birlikte, toplumumuzun yapısına, ihtiyaçlarına ve gerçeklerine uygun ulusal yaşamboyu öğrenme stratejileri belirleyip, bu doğrultuda gerekli bütçe ve insan kaynaklarını tedarik edip, oluşturulacak bir eylem planı dâhilinde faaliyet gösterebilir.

- Yükseköğretim kurumlarında yaşamboyu öğrenmenin mesleki gelişimin ötesinde öğretim elemanlarının bütünsel gelişimini kapsadığı anlayışının yaygınlaştırılmasına yönelik faaliyetler yapılabilir.

- Yükseköğretim kurumlarında, öğretim elemanlarının yaşamboyu öğrenme sürecini olumsuz etkileyen faktörlerin kurum kapsamında mevcut olma düzeylerinin belirlenip, ortadan kaldırılmasına yönelik uygulamalar yapılabilir.

- Yükseköğretim kurumlarında, yaşamboyu öğrenme sürecinde öğretim elemanlarının tüm gelişim alanlarında kendilerini ilerletmeleri konusunda maddi ve manevi olarak kurumsal destekler sunulabilir.

- Akademik yükseltmelerde ve atamalarda öğretim elemanlarının bütünsel gelişimleri kapsamında farklı alanlardaki gelişimlerini ve faaliyetlerini içeren yeni kriterler belirleyerek uygulamaya konulabilir. Böylece akademisyenlerin kendilerini çok yönlü gelişmeleri teşvik edilebilir.

- Yükseköğretim kurumlarında, öğretim elemanlarının etik bilinçlerinin güçlendirilmesine yönelik eğitsel faaliyetler yapılabilir. Bu kapsamda üniversite yönetimi tarafindan ciddi bir denetim mekanizması oluşturularak, öğretim elemanlarına kurum tarafından sunulan olanakların ne derece etkili kullanıldığı araştırılabilir.

- Öğretim elemanlarının yaşamboyu öğrenme hakkındaki görüşlerini ve yaşamboyu öğrenme özelliklerini etkileyen faktörlerin incelenmesine yönelik olarak, farklı üniversitelerde benzer araştırmalar yürütülebilir. 
- Benzer araştırmalar farklı ülkelerdeki üniversitelerde gerçekleştirilip, ülkemizdeki öğretim elemanlarının yaşamboyu öğrenme konusundaki mevcut durumları ile karşılaştırılabilir.

- Araştırmada belirlenen ve öğretim elemanlarının yaşamboyu öğrenme özelliklerini etkileyen faktörlere yönelik farklı ölçekler geliştirilerek, söz konusu faktörler temelinde üniversitelerde durum tespiti yapılabilir.

- Öğretim elemanların yaşamboyu öğrenme özelliklerini etkileyen faktörlere yönelik geliştirilen ölçekler ile veri toplanıp, söz konusu faktörler arasındaki ilişkisel yapıyı ortaya koymaya yönelik olarak istatistiksel modeller geliştirilebilir.

- Yaşamboyu öğrenme kapsamında öğretim elemanlarına kurum içinde sunulan eğitim etkinliklerinin niteliğinin yükseltilebilmesi konusunda eylem araştırmaları gerçekleştirilebilir.

- Toplumun yaşamboyu öğrenme anlayışının belirlenmesi ve bu anlayışın öğretim elemanları üzerindeki etkilerini belirlemeye yönelik disiplinler arası araştırmalar gerçekleştirilebilir. 


\section{Kaynakça}

Adams, D. N. (2007). Lifelong learning skills and attributes: The perceptions of Australian secondary school teachers. Issues in Educational Research., 17, 1-12.

AGE (2014). Lifelong learning - A tool for all ages. 24.07.2015 tarihinde http://www.ageplatform.eu/images/stories/EN/AGE_leaflet_lifelong_learning.pdf adresinden ulaşılmıştır.

Aggarwal, N. (2013). Faculty development in a flexible learning context. Procedia Social and Behavioral Sciences, 93, 1329-1332.

Anadolu Üniversitesi (2014). Yaşamboyu öğrenme. 10.10.2014 tarihinde http://aof.mezun.anadolu.edu.tr/yboyuogrenme.htm adresinden ulaşılmıştır.

Banks, C. H. (2002). A descriptive analysis of the perceived effectiveness of Virginia Tech's Faculty Development Institute. Yayınlanmamış doktora tezi, Virginia Technology University.

Biesta, G. J. J. (2011). Learning democracy in school and society: Education, lifelong learning and the politics of citizenship. Rotterdam: Sense Publisher.

Brown, L. A. (2001). An evalution of faculty development in technology. Yayınlanmamış yüksek lisans tezi, The University of Alaska Anchorage.

Bruce, T. (2011). Early childhood education (4. Bask1). London: Hodder Education.

Bryce, J. (2006). Schools and lifelong learners. J. Chapman, P. Cartwright ve E. J. McGilp (Eds.), Lifelong learning, participation and equity içinde (s. 243-263). Dordrecht: Springer.

Cedefop (2003). Lifelong learning: Citizens' views. Luxembourg: Office for Official Publications of the European Communities.

Clapper, T. C. (2010). Beyond Knowles: What those conducting simulation need to know about adult learning theory. Clinical Simulation in Nursing, 6(1), e7-e14.

Cornford, I. R. (2002). Learning-to-learn strategies as a basis for effective lifelong learning. International Journal of Lifelong Education, 21(4), 357-368.

Crowther, J. (2004). "In and against" lifelong learning: Flexibility and corrosion of character. International Journal of Lifelong Education, 23(2), 125-136.

Çubukçu, Z. (2011). Yaşam boyu öğrenmenin gereği olarak bilgi ve iletişim teknolojileri. EJournal of New World Science Academy, 6(1), 1023-1038. 
Diker-Coşkun, Y., Kızılkaya Cumaoğlu, G. ve Seçkin, H. (2013). Bilgisayar öğretmen adaylarının bilişim alanıyla ilgili okuryazarlık kavramlarına yönelik görüşleri. International Journal of Human Sciences, 10(1), 1259-1272.

Dinevski, D. ve Kokol, D. P. (2005). ICT and lifelong learning. 27.07 .2015 tarihinde http://www.eurodl.org/materials/contrib/2004/Dinevski.html adresinden ulaşılmıştır.

Dong, W. (2004). Improving students' lifelong learning skills in circuit analysis. The China Papers, November, 75-78.

Duta, N. ve Rafaila, E. (2014). Importance of the lifelong learning for professional development of university teachers - needs and practical implications. Procedia Social and Behavioral Sciences, 127, 801-806.

Edwards, R. (1997). Changing places? Flexibility, lifelong learning and a learning society. NY: Routledge.

ELLI (2010). Making lifelong learning tangible! : The European ELLI index 2010. 25.07.2015 tarihinde http://www.elli.org/fileadmin/user_upload/About_ELLI/Documents/ELLI_ EU_eng_final.pdf adresinden ulaşılmıştır.

Endrawes, G. (2010). Transferable skills and lifelong learning. 4th International Technology, Education and Development Conference (Inted 2010), 5188-5194.

European Commission (2002). European report on quality indicators of lifelong learning : Fifteen quality indicators. Brussels: European Commission.

European Commission (2006a). Adult learning: It is never too late to learn. Brussels: European Commission.

European Commission (2006b). Recommendation of the European parliament and of the council of 18 December 2006 on key competences for lifelong learning. 25.07.2015 tarihinde http://eur-lex.europa.eu/LexUriServ/LexUriServ.do?uri=OJ:L:2006:394:001 0:0018:en:PDF adresinden ulaşılmıştır.

European Commission (2007). Key competences for lifelong learning European reference framework. 20.07.2015 tarihinde ec.europa.eu/...learning/keycomp_en.pdf adresinden ulaşılmıştır.

Falch, T. ve Oosterbeek, H. (2011). Financing lifelong learning: Funding mechanisms in education and training. 27.07.2015 tarihinde http://www.eenee.de/eeneeHome/EENE E/Analytical-Reports.html adresinden ulaşılmıştır.

Falk, J. H. ve Dierking, L. D. (2012). Lifelong science learning for adults: The role of freechoice experiences. B. J. Fraser, K. G. Tobin ve C. J. McRobbie (Eds.), Second 
international handbook of science education içinde (Cilt. 1, s. 1063-1079). NY: Springer.

Figel, J. (2007). Key competences for lifelong learning: European reference framework. 25.07.2015 tarihinde http://ec.europa.eu/dgs/education_culture/publ/pdf/ll-learning/ keycomp_en.pdf adresinden ulaşılmıştır.

Flew, T. (2002). Educational media in transition: Braodcasting, digital media and lifelong learning in the knowledge economy. International Journal of Instructional Media, 29(1), 47-60.

Gibb, T. ve Walker, J. (2011). Educating for a high skills society? The landscape of federal employment, training and lifelong learning policy in Canada. Journal of Education Policy, 26(3), 381-398.

Gorard, S., Selwyn, N. ve Madden, L. (2003). Logged on to learning? Assessing the impact of technology on participation in lifelong learning. International Journal of Lifelong Education, 22(3), 281-296.

Gouthro, P. A. (2005). A critical feminist analysis of the homeplace as learning site: expanding the discourse of lifelong learning to consider adult women learners. International Journal of Lifelong Education, 24(1), 5-19.

Güleç, İ., Çelik, S. ve Demirhan, B. (2012). Yaşam boyu öğrenme nedir? Kavram ve kapsamı üzerine bir değerlendirme. Sakarya University Journal of Education, 2(3), 34-48.

Günüç, S., Odabaşı, H. F. ve Kuzu, A. (2012). Yaşamboyu öğrenmeyi etkileyen faktörler. Gaziantep Üniversitesi Sosyal Bilimler Dergisi, 11(2), 309-325.

Günüç, S., Odabaşı, H. F. ve Kuzu, A. (2014). Developing an effective lifelong learning scale (ELLS): Study of validity \& reliability. Eğitim ve Bilim, 39(171), 244-258.

Gürdal, O. (2000). Yaşamboyu öğrenme etkinliği : Enformasyon okuryazarlığı. Türk Kütüphaneciliği, 14(2), 176-187.

Hamilton, M. (2002). Sustainable literacies and the ecology of lifelong learning. R. Harrison, F. Reeve, A. Hanson ve J. Clarke (Eds.), Supporting lifelong learning içinde (s. 176187). London: RoutledgeFalmer.

Hammer, S. (2013). Enhancing learning through technology in lifelong learning. British Journal of Educational Technology, 44(6), E222-E223.

Hendrick, H. (2015). Cosntructions and reconstructions of British childhood : An interpretative survey, 1800 to present. A. James ve A. Prout (Eds.), Constructing and reconstructing childhood: Contemporary issues in the sociological study of childhood içinde (s. 2953). OX: Routhledge. 
Holmes, A. (2002). Lifelong learning. OX: Capstone Publishing.

Jarman, R., Mcaleese, L. ve Mcconnell, B. (1997). Science and lifelong learning: A survey of science teachers' provision for the promotion of pupils' independent study at key stage 4 . Evaluation \& Research in Education, 11(3), 149-163.

Jarvis, P. (2007). Globalisation, lifelong learning and the learning society : Sociological perspectives (Cilt. 2). NY: Routledge.

Jarvis, P. (2008). Democracy, lifelong learning and the learning society : Active citizenship in a late modern age (Cilt. 3). Oxon: Routledge.

Jarvis, P. (2009). Learning to be a person in society learning to be me. K. İlleris (Ed.), Contemporary theories of learning : Learning theorists in their own words içinde (s. 2134). Oxon: Routhledge.

Jarvis, P. (2012). Adult learning in social context. Oxon: Routhledge.

Kato, K. (2013). University teacher training in Japan. Revista de Docencia Universitaria, 11(3), 53-63.

Kaya, H. E. (2014). Yaşamboyu öğrenme ve Türkiye. Ankara University Journal of Faculty of Educational Sciences, 47(1), 81-102.

Kirby, J. R., Knapper, C., Lamon, P. ve Egnatoff, W. J. (2010). Development of a scale to measure lifelong learning. International Journal of Lifelong Educational and Psychological Measurement, 29(3), 291-302.

Knapper, C. ve Cropley, A. J. (2000). Lifelong learning in higher education (3. Bask1). London: Kogan Page Limited.

Knoche, L. L., Cline, K. D. ve Marvin, C. A. (2012). Fostering collaborative partnership between early childhood prefessionals and the parents of young children. R. C. Pianta, W. S. Barnett, L. M. Justice ve S. M. Sheridan (Eds.), Handbook of early childhood education içinde (s. 370-392). NY: The Guilford Press.

Knowles, M. (2009). Yetişkinlerde öğrenme konusunda yeni bir teknoloji. A. Yıldız ve M. Uysal (Eds.), Yetişkin eğitimi içinde (s. 127-144). İstanbul: Kalkedon Yayınları.

Koç, G. (2007). Yaşam boyu öğrenme. Ö. Demirel (Ed.), Eğitimde yeni yönelimler içinde (s. 209-222). Ankara: Pegem Yayınc1lı.

Kokhanova, L. A. (2012). The mass media and nongovernmental organizations in education tarihinde http://www.eolss.net/sample-chapters/c11/e1-12-05-05.pdf adresinden ulaşılmıştır.

Koper, R. (2004). Editorial: Technology and lifelong learning. British Journal of Educational Technology, 35(6), 675-678. 
Köğce, D., Özpınar, İ., Mandacı Şahin, S. ve Aydoğan Yenmez, A. (2014). Öğretim elemanlarının 21. yüzyıl öğrenen standartları ve yaşamboyu öğrenmeye ilişkin görüşleri. Dicle Üniversitesi Ziya Gökalp Eğitim Fakültesi Dergisi, 22(2014), 185-213.

Köymen, Ü. (2002). Güdüleyici öğrenme. A. Şimşek (Ed.), Sınıfta demokrasi içinde (s. 111145). Ankara: Eğitim Sen Yayınları.

Laal, M. (2013a). Lifelong learning and technology. Procedia - Social and Behavioral Sciences, $83,980-984$.

Laal, M. (2013b). Key necessities for lifelong learning. 2nd World Conference on Educational Technology Research, 83, 937-941.

Latchem, C., Odabaşı, F. H. ve Kabakçı, I. (2006). Online professional development for university teaching in Turkey: A proposal. The Turkish Online Journal of Educational Technology, 5(3), 20-26.

Loyens, S. M. M., Magda, J. ve Rikers, R. M. J. P. (2008). Self-directed learning in problembased learning and its relationships with self-regulated learning. Educational Psychology Review, 20(4), 411-427.

Lunde, J. P. ve Healy, M. M. (2002). The basics of faculty development committees. K. H. Gillespie, L. R. Hilsen ve E. C. Wadsworth (Eds.), A guide to faculty development : Practical advice, example and resource içinde (s. 251-257). MA: Anker Publishing Company Inc.

Lunenberg, M., Korthagen, F. ve Swennen, A. (2007). The teacher educator as a role model. Teaching and Teacher Education, 23(5), 586-601.

Lynch, H. (2008). Lifelong learning, policy and desire. British Journal of Sociology of Education, 29(6), 677-689.

Martin, I. (2004). Citizenship, democracy and lifelong learning. International Journal of Educational Development, 24(1), 107-108.

Medel-Añonuevo, C., Ohsako, T. ve Mauch, W. (2001). Revisiting lifelong learning for the 21st century. tarihinde http://www.unesco.org/education/uie/pdf/revisitingLLL.pdf adresinden ulaşılmıştır.

Milli Eğitim Bakanlığı (2012). Milli Ĕgitim Bakanlı̆̆ ile Anadolu Üniversitesi’nden Avrupalı Türklere hayat bоуи ӧğretim protokolü. 10.10.2014 tarihinde http://hbogm.meb.gov.tr/www/milli-egitim-bakanligi-ile-anadolu-universitesi8217nde n-avrupali-turklere-hayat-boyu-ogretim-protokolu/icerik/31 adresinden ulaşılmıştır.

Morgan-Klein, B. ve Osborne, M. (2007). The concepts and practice of lifelong learning. Oxon: Routledge. 
Nyiri, R. B. (1997). The relationship between effective teaching, lifelong learning and the implementation of current best practices. USA: Duquesne University.

Phoenix, D. A. (2002). A culture of lifelong learning? Journal of Biological Education, 37(1), 4-5.

Preece, J. (2009). Lifelong learning and development. London: Continuum International Publishing.

Rotwell, W. J. ve Kazanas, H. C. (1998). Mastering the instructional design proves: A systematic approach (2. Bask1). San Francisco: Jossey-Bass.

Scales, P. (2008). Teaching in the lifelong learning sector. Buckingham: Open University Press.

Schunk, K. ve Pintrich, P. R. (2002). Motivation in education: Theory, research and application. NJ: Merrill Prentice Hall.

Selvi, K. (2011). Öğretmenlerin yaşamboyu öğrenme yeterlilikleri. Uluslararası Ĕ̆gitim Programları ve Öğretim Çalışmaları Dergisi, 1(1), 61-69.

Slavin, R. (1994). Educational psychology. USA: Paramount Publishing.

Soran, H., Akkoyunlu, B. ve Kavak, Y. (2006). Yaşamboyu öğrenme becerileri ve eğiticilerin eğitimi programı : Hacettepe Üniversitesi örneği. Hacettepe Üniversitesi Ĕ̆itim Fakültesi Dergisi, 30, 201-210.

Stasane, J. (2008). Information literacy for lifelong learning. Society, Integration, Education, Proceedings, 473-480.

Steward, A. (2009). Continuing your professional development in lifelong learning. London: Continuum International Publishing.

Stewart, A. (2009). Continuing your professional development in lifelong learning. London: Continuum International Publishing.

Strain, M. (1998). Towards an economy of lifelong learning: Reconceptualising relations between learning and life. British Journal of Educational Studies, 46(3), 264-277.

Tan, C. L. ve Morris, J. S. (2006). Undergraduate college students, laptop computers, and lifelong learning. The Journal of General Education, 54(4), 316-338.

Thompson, D. (2008). Flexibility and lifelong learning: Policy, discourse and politics. Educational Review, 60(2), 221-223.

Toprak, M. ve Erdoğan, A. (2012). Yaşamboyu öğrenme: Kavram, politika, araçlar ve uygulama. Journal of Higher Education and Science, 2(2), 69-91.

Tuschling, A. ve Engemann, C. (2006). From education to lifelong learning: The emerging regime of learning in the European Union. Educational Philosophy and Theory, 38(4), 451-469. 
UNESCO (2013). Lifelong learning. 20.11.2013 tarihinde http://uil.unesco.org/home/ programme-areas/lifelong-learning-policies-and-strategies/news-target/lifelonglearning/9bf043146eaa0985e05daa9e12135f5b/adresinden ulaş1lmıştır.

Uzunboylu, H. ve Hürsen, Ç. (2011). Lifelong learning competence scale (LLLCS) : The study of validity and reliability. Hacettepe Üniversitesi Ĕ̈itim Fakültesi Dergisi, 41, 449-460.

Van Weert, T. (2005). Lifelong learning in the knowledge society - Implications for education. Education and the Knowledge Society: Information Technology Supporting Human Development, 15-25.

Varavarn, K. K. (2010). Towards lifelong learning tarihinde http://www.unesco.org/fileadmin/ MULTIMEDIA/INSTITUTES/UIL/confintea/pdf/speeches/confinteavi_varavarn_en.pd f adresinden ulaşılmıştır.

Walters, S. ve Watters, K. (2001). Lifelong learning, higher education and active citizenship: From rhetoric to action. International Journal of Lifelong Education, 20(6), 471-478.

Warren, S. (2004). Creating a learning society? Learning careers and policies for lifelong learning. Journal of Education Policy, 19(1), 105-109.

Wolflin, R. (1999). Understanding overloaded adults' readiness level for learning: McClusky’s Theory of Margin refuted. 18th Annual Midwest Research-to-Practice Conference in Adult Continuing, and Community Education, 22-24 Eylül, Missouri.

Yasukawa, K. (2009). Teaching in post-compulsory education: skills, standards and lifelong learning. Studies in Continuing Education, 31(3), 324-325.

Yavuz-Konokman, G. ve Yanpar-Yelken, T. (2012). Öğretim elemanlarının yaşam boyu öğrenme yeterliklerine ilişkin görüssleri. 2. Ulusal Eğitim Programlarl ve Öğretim Kongresi 27-29 Eylül, Abant İzzet Baysal Üniversitesi.

Yavuz-Konokman, G. ve Yanpar-Yelken, T. (2014). Eğitim fakültesi öğretim elemanlarının yaşam boyu öğrenme yeterliklerine ilişkin algıları. Hacettepe Üniversitesi Ĕ̆itim Fakültesi Dergisi, 29(2), 267-281.

Yıldırım, A. ve Şimşek, H. (2011). Sosyal bilimlerde nitel araştırma yöntemleri (8. Baskı). Ankara: Seçkin Yayıncılık. 